\title{
Decoy Technology as a Promising Therapeutic Tool for Atherosclerosis
}

\author{
Maryam Mahjoubin-Tehran ${ }^{1}$, Yong Teng ${ }^{2} \odot$, Amin Jalili ${ }^{1}$, Seyed Hamid Aghaee-Bakhtiari ${ }^{3}$, \\ Alexander M. Markin ${ }^{4}\left(\mathbb{D}\right.$ and Amirhossein Sahebkar ${ }^{5,6,7, *(\mathbb{D})}$
}

1 Department of Medical Biotechnology and Nanotechnology, Faculty of Medicine, Mashhad University of Medical Sciences, Mashhad 9177948564, Iran; mahjoubintm951@mums.ac.ir (M.M.-T.); jalilia@mums.ac.ir (A.J.)

2 Department of Oral Biology and Diagnostic Sciences, Dental College of Georgia, Augusta University, Augusta, GA 30912, USA; yteng@augusta.edu

3 Bioinformatics Research Group, Mashhad University of Medical Sciences, Mashhad 9177948564, Iran; aghaeibh@mums.ac.ir

4 Laboratory of Cellular and Molecular Pathology of Cardiovascular System, Institute of Human Morphology, 3 Tsyurupa Street, 117418 Moscow, Russia; alexander.markin.34@gmail.com

5 Applied Biomedical Research Center, Mashhad University of Medical Sciences, Mashhad 9177948564, Iran

6 Biotechnology Research Center, Pharmaceutical Technology Institute, Mashhad University of Medical Sciences, Mashhad 9177948564, Iran

7 School of Pharmacy, Mashhad University of Medical Sciences, Mashhad 9177948564, Iran

* Correspondence: amir_saheb2000@yahoo.com

Citation: Mahjoubin-Tehran, M.; Teng, Y.; Jalili, A.; Aghaee-Bakhtiari, S.H.; Markin, A.M.; Sahebkar, A. Decoy Technology as a Promising Therapeutic Tool for Atherosclerosis. Int. J. Mol. Sci. 2021, 22, 4420 https://doi.org/10.3390/ijms22094420

Academic Editor: Łukasz Bułdak

Received: 19 March 2021

Accepted: 21 April 2021

Published: 23 April 2021

Publisher's Note: MDPI stays neutral with regard to jurisdictional claims in published maps and institutional affiliations.

Copyright: (c) 2021 by the authors. Licensee MDPI, Basel, Switzerland. This article is an open access article distributed under the terms and conditions of the Creative Commons Attribution (CC BY) license (https:/ / creativecommons.org/licenses/by/ $4.0 /)$.

\begin{abstract}
Cardiovascular diseases (CVDs) have been classified into several types of disease, of which atherosclerosis is the most prevalent. Atherosclerosis is characterized as an inflammatory chronic disease which is caused by the formation of lesions in the arterial wall. Subsequently, lesion progression and disruption ultimately lead to heart disease and stroke. The development of atherosclerosis is the underlying cause of approximately $50 \%$ of all deaths in westernized societies. Countless studies have aimed to improve therapeutic approaches for atherosclerosis treatment; however, it remains high on the global list of challenges toward healthy and long lives. Some patients with familial hypercholesterolemia could not get intended LDL-C goals even with high doses of traditional therapies such as statins, with many of them being unable to tolerate statins because of the harsh side effects. Furthermore, even in patients achieving target LDL-C levels, the residual risk of traditional therapies is still significant thus highlighting the necessity of ongoing research for more effective therapeutic approaches with minimal side effects. Decoy-based drug candidates represent an opportunity to inhibit regulatory pathways that promote atherosclerosis. In this review, the potential roles of decoys in the treatment of atherosclerosis were described based on the in vitro and in vivo findings.
\end{abstract}

Keywords: decoy; atherosclerosis; cardiovascular disease

\section{Introduction}

Atherosclerosis is a leading etiology of cardiovascular disease (CVD). Atherosclerosis is characterized as an inflammatory process in the arterial wall that can lead to artery diseases and stroke [1,2]. Atherosclerosis underlies several important vascular pathological condition events such as peripheral arterial diseases and coronary diseases, which cause most morbidity and mortality from CVD. Cholesterol is a critical component of atherosclerotic plaques, which promotes foam cell formation and perpetuates atherosclerosis development. High plasma levels of pro-atherogenic lipoproteins such as low-density lipoprotein (LDL) and very low-density lipoprotein (VLDL) as well as VLDL remnants are considered among primary risk factors for the progression of atherosclerosis [3,4]. Atherosclerotic CVD mainly targets the vessels in the heart and brain resulting in ischemic 
heart disease and ischemic stroke [5,6]. Ischemic heart disease and stroke are presented as the first and fifth causes of death globally, respectively $[7,8]$. Many clinical and experimental studies have been performed to develop drugs for atherosclerosis.

\section{Therapeutic Approaches for Atherosclerosis}

\subsection{Lipid-Lowering Therapies}

Lipid-lowering therapy is the major current strategy in managing atherosclerotic cardiovascular disease. LDL is an important atherosclerotic risk factor lying at the root of human atherosclerosis. Many attempts to develop drugs for atherosclerosis have been designed to reduce the plasma level of LDL cholesterol, as well as other detrimental lipids and lipoproteins including triglyceride-rich lipoproteins [9]. Statins are the cornerstone of lipid-lowering therapy owing to their LDL-lowering and pleiotropic effects [10-13]. However, these drugs are not without adverse effects. For instance, muscle symptoms in extreme cases can lead to complete drug intolerance and discontinuation [14].

\subsection{Antioxidant Interventions}

Almost all schemes of the pathogenesis of atherosclerosis invoke oxidative modified LDL as a key instigating factor. Various phospholipases can liberate lipid moieties from oxidized lipoproteins that can activate deleterious functions of vascular cells and leukocytes found in atheromata. Yet, several attempts to inhibit phospholipases to prevent the generation of these putatively pernicious mediators have not borne fruit [15].

\subsection{Anti-Inflammatory Interventions}

The role of inflammatory pathways in the pathogenesis of atherosclerosis has been demonstrated. Some studies were designed to target various inflammatory pathways in secondary prevention of atherosclerotic events [16]. A hallmark of inflammation is the recruitment of leukocytes, which is a process depending on endothelial-leukocyte expression. In addition to endothelial cells, platelets contain one such adhesion molecule, P-selectin. This double source points to a pivotal role of this particular adhesion molecule in acute inflammation complicated by thrombosis [17]. Moreover, the (NOD-, LRR-, and pyrin domain-containing protein 3) (NLRP3) inflammasome regulates the activity of its constituent protein caspase- 1 . The inflammasome undergoes activation by a number of pathogen-associated molecular patterns and damage-associated molecular patterns. Several atherosclerosis-related stimuli also can coactivate the NLRP3 inflammasome [15].

\subsection{Potential Vaccinations}

Scientific evidence during the past 40 years has implicated an adaptive immune response against plaque-associated autoantigens in atherogenesis. Preclinical data have underscored the protective potential of immunization against such targets precisely [18]. Existence of both proatherogenic and athero-protective immune responses have led to the notion that suppressing proatherogenic immune response or activation of an atheroprotective immune response may be beneficial for atherosclerosis. These pathophysiological principles hence raise the tantalizing possibility that immune modulation using a vaccine or specific antibody could favorably alter the natural history of atherosclerosis. Modifications of the immune response using a vaccine containing antigen(s) relevant to atherogenesis may promote specific immune responses against relevant antigens with the potential for a more sustained effect, but not affect the global immunity [19].

Despite the efficacy of conventional drugs such as statins, there is limited response in certain groups such as patients with familial hypercholesterolemia patients [20]. In addition, many statin-treated patients remain at a high risk of residual CVD risk despite reaching LDL-cholesterol goals [3]. Furthermore, these drugs have many side effects such as elevation of liver enzyme concentrations [21], drug-drug interactions [22], and myopathy disorders [23]. Thereby, the search for more effective drugs with fewer side effects for atherosclerosis treatment has continued. 
In addition to protein-based therapeutics (recombinant proteins and antibodies), efforts have been made toward the development of nucleic acid-based drugs which are stable and have longer half-lives than protein-based therapeutics [24,25]. The nucleic acidbased therapeutic approach includes antisense oligonucleotides (ASO), small interfering RNAs (siRNA), MicroRNAs (miRNA), and decoys [26].

\section{Decoy}

\subsection{Decoy Oligodeoxynucleotides (ODN)}

Decoy ODNs are short double-stranded deoxyribonucleic acid (DNA) that have a similar sequence as DNA-binding site of transcription factors (TF) and can selectively block TF activation of target genes [27]. Decoy ODN technology aims to inhibit expression of target genes at the transcriptional level through competition for trans elements of the regulatory regions of genes (Figure 1) [28-30]. Due to the specificity, finding the best sequence of TF binding sites for regulation of the target gene expression is one of the technical obstacles of this method [31]. The use of decoy ODNs as a therapeutic tool has been established for many years for various diseases including cancers [32]. Decoy transfection is a promising tool for inhibition of gene activation. Although the decoy could be synthesized easily, the effectiveness of in vivo delivery remains difficult [33]. Moreover, a great deal of research has been focused on improving pharmacological characteristics such as biostability, resistance to serum nucleases, cell adsorption, and nuclear localization of decoy ODNs by modifications such as peptide nucleic acids, chimeric decoy oligonucleotides, and locked nucleic acids [29].

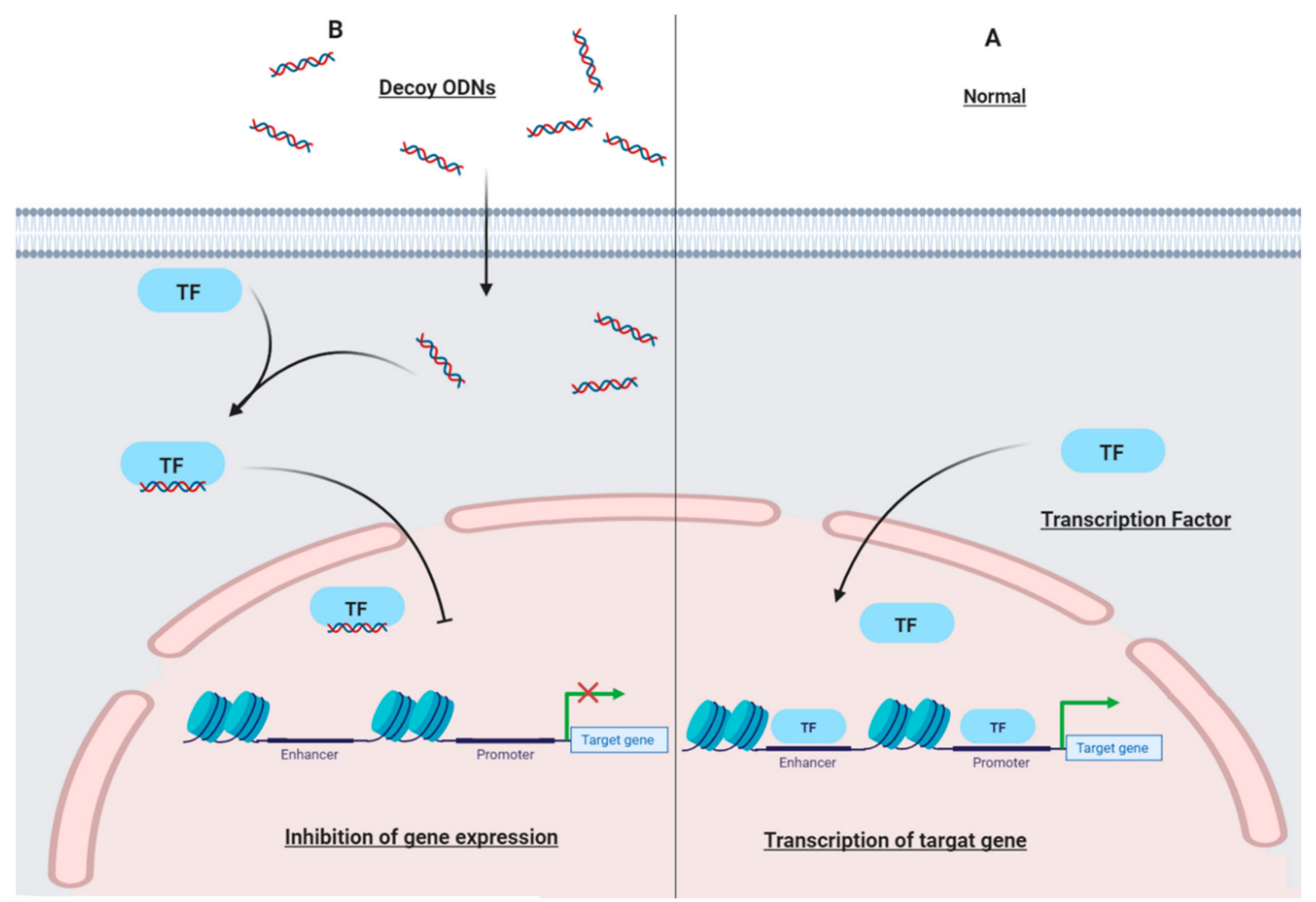

Figure 1. The mechanism of action of decoy ODNs. (A) Without decoy ODNs: normal transcription of target genes. (B) In the presence of decoy ODNs: decoy ODNs bind to a specific transcription factor. Despite entering the nucleus, the transcription factor could not bind to the specific region and promote transcription of the target gene. ODNs: oligodeoxynucleotides; TF: transcription factor. 


\subsection{Decoy Peptide}

Decoy peptides (or decoy receptors) are "sticky" proteins similar to functional receptors on cytokines and chemokines [34]. Decoy peptides are specifically designed to attract certain ligands such as inflammatory cytokines and compete with target receptors although decoy peptides do not initiate signaling (Figure 2) [35]. The decoy peptide is designed to trap the specific ligand molecules as efficiently as their respective receptor. Therefore, ligand binding to the functional receptor is inhibited and the corresponding signaling pathway is suppressed.

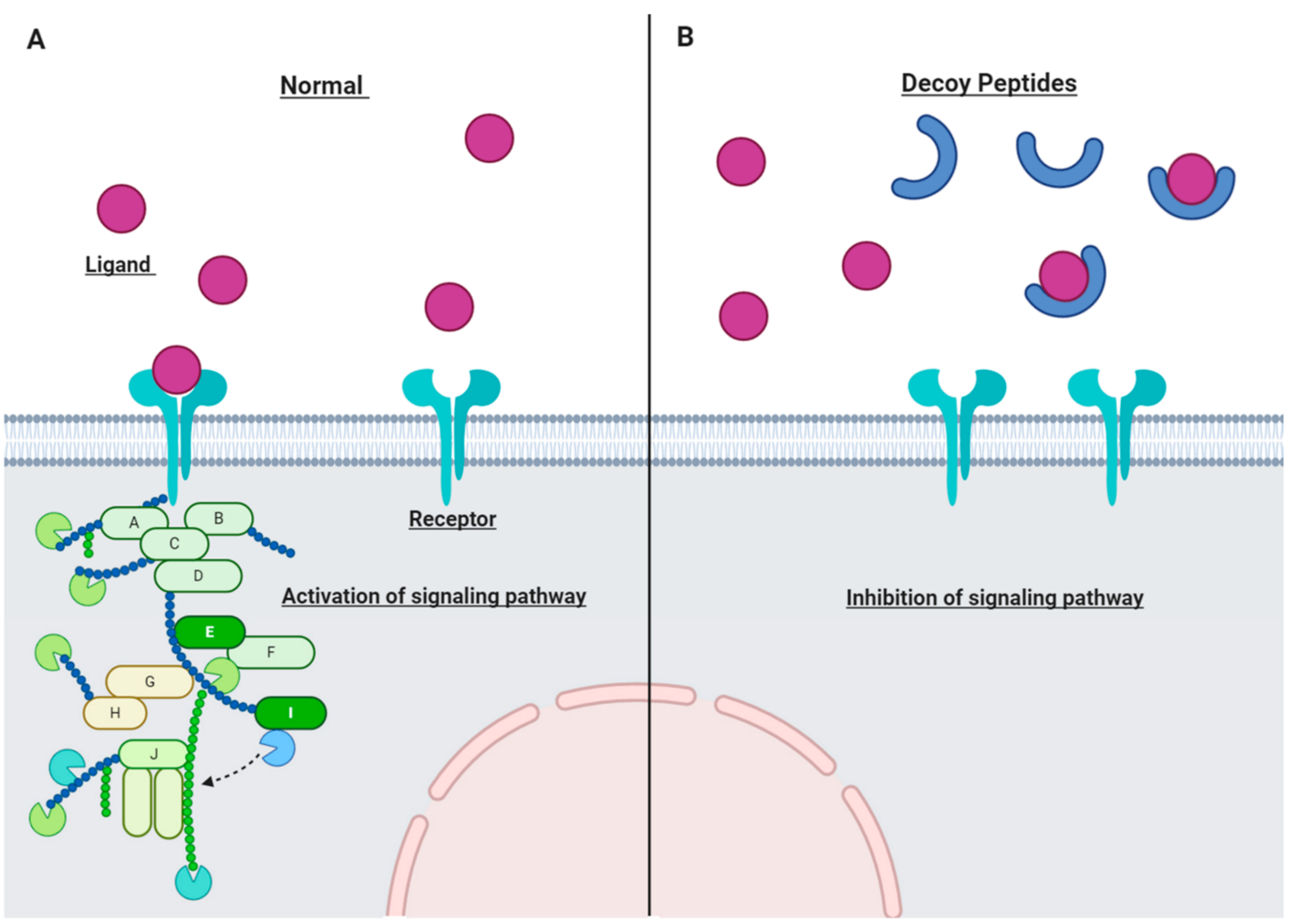

Figure 2. The mechanism of action of decoy peptides. (A) Normal cell without decoy peptides. (B) Decoy peptides act as molecular traps and bind to the specific ligands; so, the corresponding signaling pathway would be inhibited.

Decoy peptides are applied throughout various fields of research and have been demonstrated as an anticancer agent via a decoy receptor for Wnt ligands [34,36]. Importantly, decoy receptors constitute a novel and relatively unknown target for development of antiviral drugs [37] or as a therapeutic tool for inhibition of bacterial infections [38]. Moreover, decoy peptides are employed as a novel class of therapeutics for combatting neurotoxic envenoming [39]. Interestingly, decoy peptides bind to oligomeric and fibrillar amyloid $\beta$ with high affinity, form complexes, and block amyloid $\beta$ toxicity in Alzheimer's disease [40].

\section{Targets}

\subsection{Protein Phosphatase 1}

Abnormalities in vascular smooth muscle cell (VSMC) proliferation are an important etipathological factor for vascular proliferative disorders. The proliferation of VSMC is associated with a chronic increase in the cytosolic $\mathrm{Ca}^{2+}$ level, which is caused by the loss of $\mathrm{Ca}^{2+}$ handling proteins, such as sarco/endoplasmic reticulum $\mathrm{Ca}^{2+}$-ATPase (SERCA2a) [41]. The gene transfer-mediated restoration of the SERCA2a level attenuates VSMC proliferation and neointimal formation [42]. Therefore, the maintenance of a low cytosolic $\mathrm{Ca}^{2+}$ level by controlling SERCA2a activity is a reasonable strategy to prevent VSMC proliferation. 
SERCA2a activity is inhibited by a direct interaction with phospholamban, whose inhibitory activity is enhanced by dephosphorylation by protein phosphatase 1 (PP1) [43]. Therefore, the inhibition of the PP1-mediated dephosphorylation of PLB is a promising approach to upregulate SERCA2a activity [44].

Jang et al. used the peptide decoy, named $\psi$ PLB-SE, to target protein phosphatase 1 in cardiomyocytes and thereby normalize the activity of SERCA2a. Their results indicated that $\psi$ PLB-SE reduced neointimal growth in balloon-injured rat carotid arteries, as well as VSMC proliferation and migration. Furthermore, $\psi$ PLB-SE could also inhibit SERCA2a degradation in injured rat carotid arteries. They concluded that $\psi$ PLB-SE could correct the handling of abnormal Ca2+ by activating SERCA2a [44].

\subsection{Macrophage Scavenger Receptors}

Macrophage scavenger receptors (MSRs) induce the formation of atherosclerotic lesions. MSRs can efficiently bind and internalize atherogenic modified LDL such as acetylated LDL and oxidized LDL in the vessel wall causing the lipids deposition in the arterial wall. Furthermore, they facilitate cation-independent adhesion of macrophages and promote lesion development [45]. Since MSRs are not downregulated by the accumulation of lipids in the cell, accumulation of lipids in the lesion macrophages continues [45]. Soluble decoy receptors have the potential to be effective tools for inhibiting receptor-mediated functions [46].

Jalkanen and colleagues generated a modified MSR known as a secreted macrophage scavenger receptor (sMSR), which contained the human MSR AI extracellular domains and signal sequence. Results showed that this sMSR decoy reduced the degradation of atherogenic modified LDL. Monocyte/macrophage adhesion on endothelial cells was decreased, and macrophage foam cell formation was inhibited in SMSR decoy treatment [45]. In another study for testing the long-term effects, an sMSR decoy was transduced to Westerntype diet fed LDL receptor (LDLR) knockout mice via an adeno-associated virus (AAV). sMSR decoy protein was detected in the transduced mice plasma 6 months after the gene transfer. The sMSR decoy significantly reduced atherosclerotic lesions in the aorta by $21 \%$ compared to the control [46]. The sMSR decoy was also transduced to the hypercholesterolemic LDLR knockout mice via a recombinant adenovirus. The results revealed that while atherosclerotic lesions in the whole aortic area were reduced, the change in the aortic root was not statistically significant [47].

\subsection{Activator Protein-1}

VSMCs migration and proliferation are common characteristics of responses in vascular diseases with various factors being involved in the process [48]. Studies showed that in balloon-injured arteries, transcription factor activator protein-1 (AP-1) is upregulated in injured arterial smooth muscle cells [48]. Moreover, transforming growth factor- $\beta 1$ (TGF- $\beta 1$ ) has been implicated in the development of human restenosis after angioplasty as well as in neointimal lesions in balloon-injured arteries. TGF- $\beta 1 \mathrm{mRNA}$ levels were found to be increased in restenotic lesions. It is worth noting that the TGF- $\beta 1$ gene has an AP-1 consensus sequence in its promoter region [49]. One of the mechanisms of neointimal thickening suppression by AP-1 decoy is suppression of VSMC proliferation by blocking platelet-derived growth factor (PDGF)-mediated MAP kinase (MAPK) and AP-1 signaling pathways and TGF- $\beta 1$ production [48].

Kume et al. transferred decoy ODNs containing the AP-1 binding site in ballooninjured rabbit carotid arteries. They used the hemagglutinating virus of Japan (HVJ) liposomes method in conjunction with human aortic SMCs in order to reduce AP-1 activity and examine its effects on neointimal thickening. Result showed that the decoy reduced AP-1 DNA-binding activity due to specific binding of the decoy to AP-1 in vivo as well as a reduction of the neointimal area. Furthermore, they showed that the AP- 1 decoy decreased the cell number of SMCs. TGF- $\beta 1$ could also reduce SMCs production under stimulation of platelet-derived growth factors. Transfection of VSMCs with this decoy 
prevented transactivation of some vital cell-cycle regulatory genes; in that way inhibiting proliferation of VSMC and remodeling the vascular wall. As a result, they suggested the AP-1 decoy as a novel therapeutic approach for restenosis [48].

Neointimal formation and intimal hyperplasia is the main cause of late vein graft failure; in which proliferation and migration of SMCs are the underlying mechanisms. AP-1 plays a role in the expression of many genes involved in cellular proliferation, cell cycle progression, extracellular matrix production, and neointimal formation after vascular injury.

Ahn and his associates transfected the AP- 1 decoy as a therapeutic strategy for restenosis after angioplasty. The AP-1 decoy blocked proliferation and migration of VSMCs. The decoy also inhibited the formation of neointimal after balloon injury in the rat carotid artery [50]. In another study, this group evaluated the effects of the AP-1 decoy on intimal hyperplasia within a large animal model using mongrel dogs. The results indicated that the AP-1 decoy effectively inhibited intimal hyperplasia of an autogenous vein graft [51].

Xie and his coworkers investigated the effect of cardiac fibroblasts (CFs) transfection with the AP-1 decoy to determine if it would prevent proliferation of $\mathrm{CF}$ and expression of the matrix metalloproteinase (MMP) gene. Rat heart CFs were cultured and exposed to xanthine 1 xanthine oxidase $(\mathrm{XXO})$ as well as AP-1 decoy ODNs. It was found that the decoy could inhibit $\mathrm{XXO}$-induced proliferation of $\mathrm{CF}$ and expression of MMP genes in vitro [52].

\subsection{Cyclic Adenosine Monophosphate Response Element}

Intimal hyperplasia is a major reason for treatment failure following vascular and endovascular surgery (VES). It has been demonstrated that blunting the activation of cyclic adenosine monophosphate response element (CRE) binding protein is critical in preventing vein graft intimal hyperplasia [53].

Uchida et al. designed a CRE decoy for binding to a CRE sequence for preventing intimal hyperplasia. The results showed that the CRE decoy decreased VSMC proliferation and migration. Furthermore, the CRE decoy not only decreased CRE activity but also suppressed the intimal hyperplasia formation at injured vessel walls in mice [54].

\subsection{Early Growth Response Factor-1}

Early growth response factor-1 (Egr-1) is an important transcription factor in promoting atherosclerosis. Since Egr-1 can be quickly activated after vascular injury, it may have a critical role in vascular proliferation and inflammation [55]. The excess VSMC proliferation and the intimal hyperplasia development is a hallmark of vein graft failure. Egr-1 could contribute to vascular proliferation and inflammation. Wang et al. transfected Egr-1 decoy ODNs to the vein graft of rabbits to evaluate their effects on the thickness of the intima. They found that Egr-1 decoy ODNs decreased the expression of Egr-1 as well as reduced VSMC proliferation and intimal hyperplasia [56].

Egr-1 has a master regulatory role in cardiovascular diseases such as atherosclerosis and restenosis. Han and colleagues designed an Egr-1 decoy in balloon-injured arteria of rats. The results showed that Egr-1 decoy could not down regulate the expression of Egr-1. The Egr-1 decoy, however, proved to effectively block downstream genes such as proliferating-cell nuclear antigen (PCNA), cyclinD1, and cyclin-dependent kinases 4 (cdk4), thus inhibiting VSMC proliferation and neointimal hyperplasia [57].

An experiment conducted by Ohtani et al. evaluated the effect of the Egr-1 decoy for the treatment of atherosclerosis and restenosis. The Egr-1 decoy was quickly intraluminally transfected to the hypercholesterolemic rabbits subsequent to the carotid artery balloon injury. The results demonstrated that Egr-1 activity was increased after balloon injury but was prevented by the Egr-1 decoy. Furthermore, the Egr-1 decoy reduced the expression of Egr-1-dependent genes, such as platelet-derived growth factor-B (PDGF-B) and TGF- $\beta 1$, which in turn reduced early inflammation, proliferation, and later neointimal hyperplasia [55]. 
Peroulis et al. evaluated the effect of a single intra-operative vein graft transfection of decoy binding Egr-1 in the suppression of vein graft intimal hyperplasia in hypercholesterolaemic rabbits. They treated jugular vein to carotid artery interposition grafts with the Egr-1 decoy through a nondistending pressure. The Egr-1 decoy decreased the Egr-1 gene expression by $60 \%$ as well as decreased cellular proliferation. Importantly, the Egr-1 decoy reduced intimal thickness in the grafts, whereas it was increased throughout the luminal area [58].

\section{6. $E 2 F$}

E2F is a transcription factor that has an essential role in the coordinated transactivation of cell-cycle-regulatory genes which are involved in the formation of lesions subsequent to vascular injury [59]. Morishita and his research team developed a double-stranded DNA decoy with a high affinity binding ability for E2F which can bind E2F and prevent the activation of genes that mediate cell cycle and intimal hyperplasia subsequent to vascular injury. Transfection of the E2F ODN decoy via HVJ-liposome inhibited expression of c-myc, proliferating-cell nuclear antigen (PCNA) encoding genes, and vascular smooth muscle cell proliferation in the rat carotid injury. The results from two weeks after a single transfection showed that formation of neointima was inhibited through treatment with the E2F decoy; this prevention remained up to 8 weeks after transfection in a dose-dependent manner. Therefore, it was concluded that the E2F decoy can prevent SMC proliferation and the formation vascular lesions in rat carotid injury [60].

Coronary artery bypass graft surgery with autologous vein grafting is frequently performed but progressive neointimal hyperplasia still contributes to considerable vein graft failure. Edifoligide is a decoy that binds to E2F transcription factors and inhibits its effects thus preventing neointimal hyperplasia and vein graft failure. In a phase III randomized placebo-controlled trial of 3014 patients, Alexander et al. treated vein grafts ex vivo with edifoligide. Results showed that edifoligide is no more effective versus placebo in preventing vein graft failure [61]. A total of 2865 of the 3014 patients [61] were studied for 5 years and showed that death, myocardial infarction, revascularization, and rehospitalization in the decoy group were the same as the placebo [62].

E2F-1 plays a vital role in DNA synthesis as well as progression of the cell cycle. Therefore, suppressing E2F-1 has the potential to inhibit the cell cycle [63]. Edifoligide, an E2F-1 decoy, inhibited expression of cell nuclear antigen (PCNA), the proliferation of SMCs, and can prevent atherosclerosis [64].

Ehsan et al. delivered the E2F-1 decoy to graft VSMCs of rabbits. They found that this decoy could prevent the upregulation of PCNA, medial VSMC proliferation, SMC proliferation, and reduce neointimal thickness. After 6 months, the decoy group grafts stayed without macroscopic plaque grafting compared to the control group [64].

In a randomized trial containing 41 patients with graft failure, the phosphorothioate E2F-1 decoy was delivered to the human vein grafts. It was shown that the E2F-1 decoy reduced the expression of PCNA and c-myc as well as decreased stenosis. Furthermore, there were no adverse effects in the treatment group [63].

In a randomized phase II trial containing 200 patients, Grube et al. investigated the effects of the E2F-1 decoy in coronary bypass grafting for 1 year. Decoy treatment reduced critical stenosis and neointimal volume [65].

A randomized placebo-controlled phase III trial conducted by Conte et al. evaluated the effects of edifoligide in 1404 infrainguinal revascularization patients to inhibit vein graft failure for 1 year. The improvement in secondary graft patency in the treatment group (83\%) was more than the control group (78\%). Therefore, the E2F-1 decoy in vein graft treatment did not provide any protection against vein graft failure [66].

Nakamura and his research team evaluated the possibility of E2F decoy treatment to inhibit neointimal formation of a balloon-injured pig coronary artery. The E2F decoy ODN was transfected after balloon inflation, followed by angioplasty. Results from the histological evaluation and intravascular ultrasound (IVUS) confirmed that the plaque area 
was significantly reduced by a single transfection of the E2F decoy compared to the control after one month. In contrast, the E2F decoy increased luminal and total vessel areas. The acute toxicity of the E2F decoy was tested in monkeys, and no obvious side effects were detected [67].

Kawauchi et al. evaluated the effects of the E2F decoy and antisense cyclin-dependent kinase (cdk2) kinase ODN by ex vivo single intraluminal delivery into cardiac allografts of mice and Japanese monkeys through the HVJ (an artificial viral envelope-liposome method). Results showed that E2F decoy suppressed neointimal formation in mice and prevented the expression of cell-cycle regulatory genes including PCNA, c-myc, and cyclindependent kinases 2 (cdk2) for up to 8 weeks, while antisense cdk2 kinase ODN had limited effects. The E2F decoy remarkably suppressed neointimal thickening and prevented cellcycle regulatory genes in primate models whereas intimal thickening developed in the control groups. In conclusion, the E2F decoy has the potential to prevent graft arteriopathy without systemic adverse effects [68].

\section{7. $N F-\kappa B$}

Nuclear factor-kB (NF- $\mathrm{kB})$ is characterized as a transcription factor that upregulates adhesion molecules including VCAM-1, intercellular adhesion molecule 1 (ICAM-1), and endothelial leucocyte adhesion molecule-1 (ELAM-1) [69]. It was shown that NF- $\mathrm{kB}$ has an important role in vascular tissue remodeling after percutaneous coronary intervention with a stent implantation [70]. Moreover, myocardial reperfusion injury develops as a result of coordinated activation of a series of cytokine and adhesion molecule genes related to NF- $\kappa B$. This results in leukocyte attachment, secretion of cytotoxic molecules, and severe damage to myocytes and endothelial cells [71].

Miyake et al. developed a chimeric decoy for simultaneous inhibition of NFkB and E2F. The results demonstrated that the chimeric decoy could inhibit VSMC proliferation and migration more than the other two decoys but had no effect on the proliferation of endothelial cells. The chimeric decoy suppressed distal and proximal anastomotic intimal hyperplasia, accelerated re-endothelialization, and inhibited macrophage accumulation. Additionally, the chimeric decoy repressed the expression of PDGF-B and PDGF receptor-b which resulted in a decreasing of smooth muscle actin (SMA)-positive cell accumulation and also reduced the expression of the VCAM- 1 and monocyte chemoattractant protein-1 (MCP-1) genes [72].

In a clinical trial, Suzuki et al. studied the effect of the NF- $\mathrm{kB}$ decoy on the prevention of restenosis after an 8-year observation period. They transfected the NF- $\mathrm{kB}$ decoy at the stent site to prevent repeated restenosis. The patient (a man), received a percutaneous coronary intervention (PCI) with stents at both stenotic sites and the distal site but was not given a decoy at the proximal site. Evaluation after 4 and 8 years revealed suppressed development of neointimal formation in treated versus untreated sites. The analysis showed that decoy lesions were less frequent than the area with no decoy in year 8 . Furthermore, no systemic adverse effect or late thrombosis formation was detected [70].

Kim et al. injected the NF- $\mathrm{KB}$ decoy ODN into the tail vein of mice with atherosclerosis (LPS/Fat-induced mice). Treatment with the NF-KB decoy ODN decreased proinflammatory cytokines and inflammatory markers VCAM-1 and ICAM-1. In addition, the NF- $\mathrm{KB}$ decoy decreased the expression of fibrosis-related proteins, TGF- $\beta 1$, and fibronectin [73].

NF- $\mathrm{KB}$ and $\mathrm{Sp} 1$ are important transcription factors for the stimulation of various inflammatory genes involved in atherosclerosis. Lee et al. developed a chimeric decoy containing the NF- $\mathrm{kB}$ and Sp1-binding sites to suppress these transcription factors concurrently. This decoy was injected into the atherosclerotic mouse model and the results indicated that the decoy blocked the DNA-binding activity of both NF-KB and Sp1 at the transcriptional level. The serum lipid level of total cholesterol (TC) and triglyceride (TG) in the decoy-treated groups was significantly lower. Additionally, the chimeric decoy 
improved atherosclerotic changes, decreased inflammatory cytokines, and inhibited the expression of atherosclerotic markers [74].

Neointimal hyperplasia is one of the major disease processes in vein graft failure. A study conducted by Miyake et al. examined the effects of the NF- $\mathrm{kB}$ decoy on inhibition of vein graft failure. Treatment with the NF- $\kappa B$ decoy was intraoperatively transfected to the hypercholesterolemic rabbits. The NF- $\mathrm{KB}$ decoy repressed intimal hyperplasia 4 weeks after vein implantation. Furthermore, this decoy increased medial thickness which led to a reduction in intima-to-media ratio. Results also showed that treatment inhibited the macrophages recruitment and the VSMC proliferation in the neointima and increased apoptosis in VSMC [75].

Feeley et al. designed transcription factor decoys (TFD) to bind to NF- $\kappa B$. The sequences of NF- $\mathrm{kB}$ decoys were selected from the consensus NF-kB-binding site and the promoters of ICAM-1, VCAM-1, and ELAM-1. They hypothesized that these decoys could reduce the expression of adhesion molecules, decrease reperfusion injury, decrease acute rejection, and reduce graft coronary artery disease (GCAD) in cardiac allografts in rat models. NF-KB TFD treatment reduced the expression of adhesion molecules and reperfusion injury parameters as hypothesized. Allografts treated with the NF-kB decoy had higher levels of apoptosis with survival being prolonged by decoy treatment. Moreover, allografts treated with the NF- $\mathrm{kB}$ decoy had decreased myointimal proliferation and intimal:medial ratios [76].

Restenosis after endovascular intervention is one of the main limitations in the treatment of cardiovascular disease [77]. Miyake et al. used a balloon catheter-based delivery system combined with chitosan-modified PLGA carriers for delivery of the NF- $\mathrm{kB}$ decoy into target vessels during angioplasty in order to inhibit neointimal hyperplasia in rabbits. Results showed that local application of the NF- $\mathrm{KB}$ decoy inhibited neointimal formation that was associated with the suppression of NF- $\mathrm{kB}$ binding activity. The therapeutic effects of the NF- $\mathrm{kB}$ decoy were carried out by macrophage recruitment inhibition via the suppression of gene expression in genes including MCP-1, VCAM-1, and CC chemokine ligand 4 as well as through the inhibition of VSMCs growth by a reduction in the expression of cyclin $\mathrm{A}$ and PCNA. Importantly, treatment with the NF- $\mathrm{kB}$ decoy resulted in the restoration of the ECM which was associated with increased expression of phosphorylated Bcl-2 in endothelial cells [77].

Tomita and his team determined the effects of the NF- $\mathrm{kB}$ decoy on NF- $\mathrm{kB}-$ mediated genes involved in the inflammatory response of endothelial cells. The NF- $\mathrm{kB}$ decoy was transfected into endothelial cells via a liposome-mediated method. The NF- $\mathrm{KB}$ decoy blocked the binding of NF- $\mathrm{KB}$ to its specific cis element as well as inhibited TNF-induced expression of IL-6 and ICAM-1 at the mRNA and protein level [78].

Inagaki et al. investigated the efficacy of an ultrasound-microbubble-mediated in vivo delivery for NF- $\mathrm{kB}$ decoy transfection in injured mouse arteries. After establishing arterial injury in murine femoral arteries by flexible wires, NF- $\mathrm{kB}$ decoy transfection reduced the neointima/media areas. The expression of inflammatory factors was found to be enhanced in non-treated injured arteries, whereas the NF- $\mathrm{kB}$ decoy inhibited the expression [33].

VSMC proliferation and migration may lead to intimal hyperplasia during vascular injury [71]. Kiomy Osako et al. designed a decoy ODN through binding the extremities of two single strands in order to reduce non-specific binding as well as degradation of the decoy ODN from the 3-terminus, called a ribbon-type decoy ODN (R-ODN). The effects of the R-ODN on inhibition of NF- $\mathrm{KB}$ were evaluated in human aortic VSMC. The resistance to exonucleases and stability of the R-ODN in serum were more than the nonmodified decoy ODN. Results also showed that the R-ODN could inhibit MMP-9 expression and VSMC proliferation induced by TNF- $\alpha$ [71].

Yoshimura and his research partners showed that in vivo transfection of NF- $\mathrm{kB}$ decoy into a balloon-injured rat carotid artery could inhibit neointimal formation 14 days after injury. Apoptosis and the expression of p53 were upregulated in the neointimal area in the vessels transfected with the NF- $\mathrm{kB}$ decoy ODN. Additionally, ICAM-1 and VCAM-1 
expression, which were induced by balloon injury in the neointimal area, were decreased in vessels treated with the decoy. The migration of T-lymphocytes and macrophages into the media and neointima was also inhibited by the decoy [79].

In another study, Yamasaki et al. transfected the NF-KB decoy ODN into the ballooninjured pigs using a hydrogel balloon catheter. Treatment by decoy inhibited the proliferation of VSMC and reduced the neointimal areas 1 and 4 weeks after single transfection and was accompanied by a reduction in PCNA-positive stained cells. Furthermore, the expression of ICAM was inhibited leading to a reduction in migration and accumulation of macrophages [80].

\subsection{Smad}

TGF- $\beta 1$ exerts pro-atherosclerotic effects in various vascular disorders. TGF- $\beta 1$ downstream signaling involves Smads that regulate genes involved in atherosclerosis. An et al. used a Smad decoy to prevent the atherosclerosis development in the shear stress-induced ApoE-/-mice. The Smad decoy reduced the gene expression of TGF- $\beta 1$ and $\alpha$-SMA. The Smad decoy ODN suppressed the histological atherosclerotic changes and prevented extracellular matrix deposition in atherosclerotic mice [81].

\subsection{TNF-Like Cytokine $1 \mathrm{~A}$}

Tumor necrosis factor (TNF)-like cytokine 1A (TL1A), which belongs to the TNF superfamily, plays critical roles in the development of chronic inflammation [82]. TL1A receptors include decoy receptor 3 (DcR3), and death receptor 3 belongs to the TNF receptor superfamily [83].

DcR3 is an antiapoptotic soluble receptor that has pro-inflammatory functions and has a critical role in immune modulation. Chang et al. evaluated the association of circulating DcR3 levels with coronary artery disease (CAD) severity for the prediction of future major adverse cardiovascular events in 152 CAD patients. DcR3 levels were significantly higher in the high versus low and intermediate syntax score groups. Therefore, DcR3 levels were identified as an independent predictor for a high syntax score. Further results indicated that evaluated level of circulating DcR3 is associated with increased 1-year major adverse cardiovascular events in patients with multivessel CAD. Therefore, increased levels of circulating DcR3 are associated with CAD severity and could predict future major adverse cardiovascular events in patients with multivessel CAD [84].

To determine the involvement of TL1A and DcR3 in promoting atherosclerosis, Li et al. evaluated the levels of TL1A and DcR3 in the plasma of patients with CAD. Results from the multivariate analysis showed that TL1A and DcR3 levels in plasma in CAD patients were more than those of non-CAD patients. Moreover, it was shown that DcR3 and TL1A have high specificity and sensitivity for diagnosis of CAD with TL1A being positively and significantly correlated with the Syntax score in CAD patients. The circulating levels of both TL1A and DcR3 were higher in CAD patients and required more coronary artery bypass grafting than in the control subjects, thus making them potential biomarkers for diagnosing severe CAD [83].

\subsection{Sterol Regulatory Element Binding Protein (SREBP)}

SREBP controls homeostasis of lipids by regulating the expression of enzymes required for the synthesis of fatty acids, triacylglycerol, endogenous cholesterol, and phospholipids [85]. An et al. used the SREBP decoy ODN to inhibit SREBPs in high-fat diet fed hyperlipidemic mice. Results showed that the decoy could inhibit the increased expression of fatty acid synthetic pathways, including SREBP-1c, ACC1, SCD-1, FAS, and 3-Hydroxy-3-Methylglutaryl-CoA Reductase (HMGCR). Moreover, decoy treatment decreased pro-inflammatory cytokines, such as interleukin (IL)-8, IL-1 $\beta$, TNF- $\alpha$, and IL-6 expression [85]. 


\section{Conclusions}

Atherosclerosis is a systemic disease that affects arteries at different sites. Progression of atherosclerosis can lead to serious problems including heart attacks and stroke. Since traditional therapies such as statins are insufficient and sometimes are not effective, novel therapeutic strategies must be considered.

Many studies reveal that decoy technology shows promising potentials for its great efficacy in atherosclerosis and thus must continue to be studied. In this review, we outlined two main decoy strategies, namely decoy ODNs and decoy peptides in atherosclerosis treatment studies (Table 1). Decoy ODNs have the constructs of cis elements for binding of transcription factors allowing them to selectively block key transcription factors involved in atherosclerosis pathogenesis. As therapeutic tools, synthesized decoy ODNs bind and block AP-1, CRE, EGR-1, E2F, and NF-B, and have been proven to have anti-atherosclerotic effects (Figure 3). Decoy peptides act as a molecular trap and attract the ligand of the special receptor which triggers a signaling pathway in the atherosclerosis pathogenesis resulting in the inhibition of the signaling pathway. Decoy peptides that are designed to be similar to SERCA2a and macrophage scavenger receptors were effective in the reduction of atherosclerosis symptoms (Figure 3).

Further studies are warranted to support the effectiveness of decoys and evaluate the positional side effects of them in human models. Adverse events of novel therapeutic approaches, such as decoy technology in humans, are considered to be improved through additional research. Moreover, one of the major limitations of decoy ODN technology is their stability, which significantly dampens the in vivo application. Decoy ODNs are degraded by intracellular nucleases. To date, several different types of double-stranded decoy ODNs, such as circular dumb-bell double-stranded decoy ODNs [86] and modified decoy ODNs with locked nucleic acids [87], have been developed to overcome this limitation. Another important issue related to decoy technology is the delivery strategy, which determines the in vivo efficacy and/or specificity.

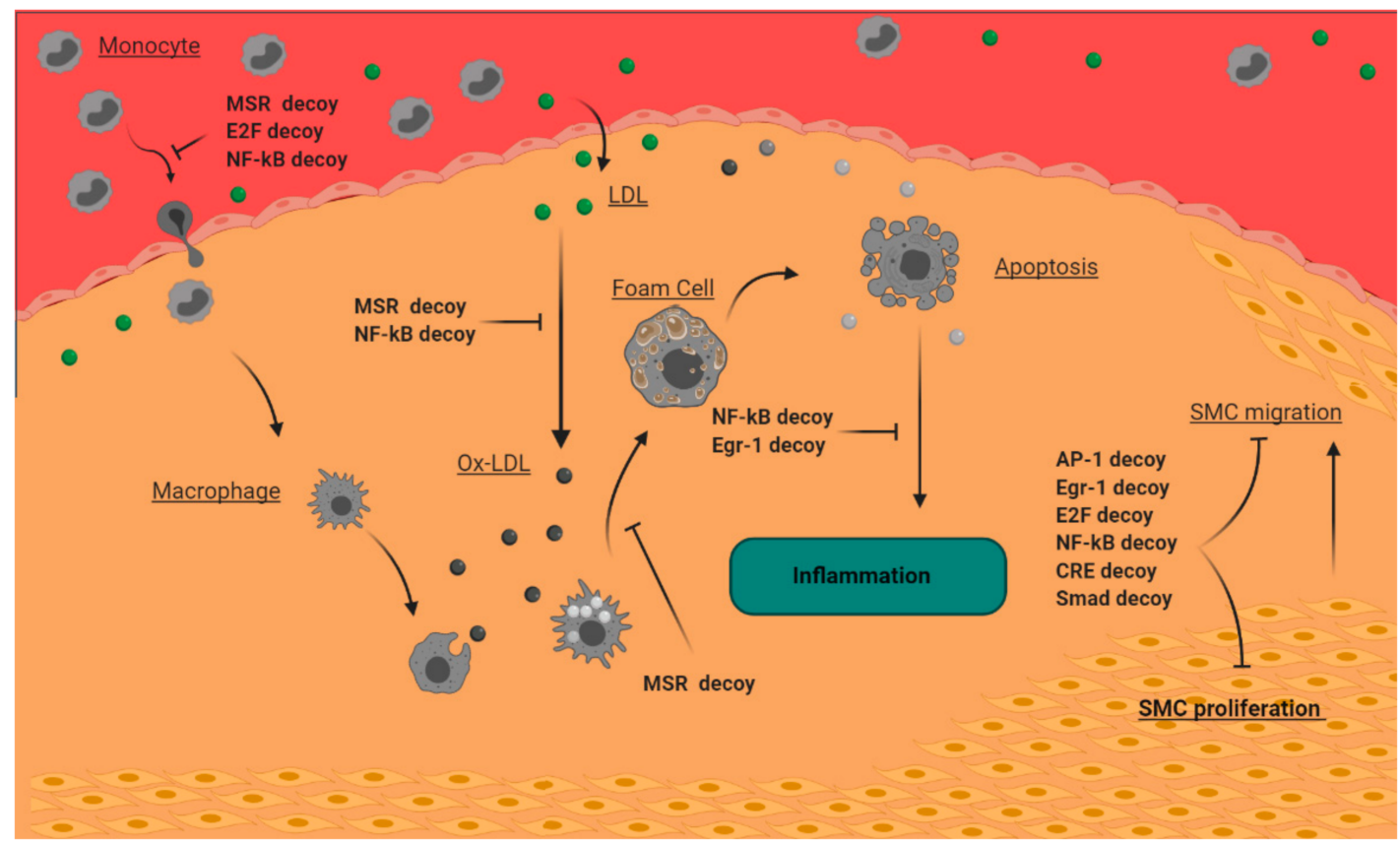

Figure 3. Anti-atherogenic mechanisms of decoys in the atherosclerosis progression. MSR and NF- $\mathrm{kB}$ decoys inhibit LDL oxidation; MSR, E2F, and NF- $\mathrm{KB}$ decoys suppress monocyte recruitment; the MSR decoy reduces foam cell formation; NF- $\mathrm{B}$ a and EGR-1 decoys reduce inflammation; AP-1, EGR-1, E2F, NF- $\mathrm{B}$, Smad, and CRE decoys inhibit SMC proliferation and migration. AP-1: activator protein-1; CRE: cyclic adenosine monophosphate response element; EGR-1: early growth response factor-1; LDL: low-density lipoprotein; MSR: macrophage scavenger receptors; NF- $\mathrm{kB}$ : nuclear factor-kB; SMC: smooth muscle cell. 
Table 1. Efficacy of decoy ODNs and decoy peptides in atherosclerosis.

\begin{tabular}{|c|c|c|c|c|c|c|c|c|}
\hline $\begin{array}{l}\text { Decoy } \\
\text { Name }\end{array}$ & Type of CVD & $\begin{array}{c}\text { Target } \\
\text { Up/Down } \\
\uparrow \downarrow\end{array}$ & $\begin{array}{c}\text { Concentration/Dose } \\
\mu \mathrm{M} \\
\mathrm{mg} / \mathrm{kg} / \mathrm{day}\end{array}$ & Decoy Type & Model/Cell Line & Delivery Method & Results & Ref. \\
\hline YPLB-SE & $\begin{array}{c}\text { Injury of the carotid artery } \\
\text { (vascular proliferative } \\
\text { disorders) }\end{array}$ & $\begin{array}{c}\text { protein } \\
\text { phosphatase } 1 \\
\downarrow\end{array}$ & $\begin{array}{c}5 \mu \mathrm{g} \text { in } 200 \mu \mathrm{l} \text { buffer } \\
\text { injection } \\
\text { for } 15 \mathrm{~min}\end{array}$ & Peptide & $\begin{array}{l}\text { Balloon-injured rat } \\
\text { carotid arteries }\end{array}$ & - & $\begin{array}{l}\text {-Preventing the SERCA2a } \\
\text { degradation in } \\
\text { VSMC-reduced neointimal } \\
\text { growth carotid artery }\end{array}$ & [44] \\
\hline sMSR & Atherosclerosis & MSR $\downarrow$ & $2.5 \mathrm{mg} / \mathrm{mL}$ & Peptide & $\begin{array}{l}\text { RAW } 264 \text { cells and } \\
\text { peritoneal mouse } \\
\text { macrophages }\end{array}$ & Adenovirus & $\begin{array}{l}\text {-Decreased adhesion of } \\
\text { monocyte/macrophage to } \\
\text { the endothelial cells } \\
\text {-Prevented the formation } \\
\text { macrophage foam cell }\end{array}$ & [45] \\
\hline sMSR & Atherosclerosis & MSR $\downarrow$ & $\begin{array}{c}\text { Single injection of } \\
7.5 \times 10^{9} \text { AAVsMSR } \\
\text { particles }\end{array}$ & Peptide & LDLR knockout mice & AAV & $\begin{array}{l}\text {-Reduced atherosclerotic } \\
\text { lesion in the aorta }\end{array}$ & [46] \\
\hline sMSR & Atherosclerosis & MSR $\downarrow$ & $1 \times 10^{9}$ & Peptide & $\begin{array}{l}\text { Hypercholesterolemic } \\
\text { LDLR knockout mice }\end{array}$ & $\begin{array}{l}\text { Recombinant } \\
\text { adenovirus }\end{array}$ & $\begin{array}{l}\text {-Reduces atherosclerotic } \\
\text { lesion area }\end{array}$ & [47] \\
\hline AP-1 Decoy & $\begin{array}{c}\text { Restenosisafter } \\
\text { angioplasty } \\
\text { Neointimal formation } \\
\text { Intimal Hyperplasia }\end{array}$ & $\mathrm{AP}-1 \downarrow$ & - & ODN & Balloon-injured Rats & HVJ-liposome & $\begin{array}{c}\text {-Inhibited VSMC } \\
\text { proliferation and migration. } \\
\text {-Abolished neointimal } \\
\text { formation after balloon } \\
\text { injury }\end{array}$ & {$[50]$} \\
\hline AP-1 Decoy & Intimal Hyperplasia & $\mathrm{AP}-1 \downarrow$ & - & ODN & Mongrel dogs & HVJ-liposome & $\begin{array}{l}\text {-Inhibited intimal } \\
\text { hyperplasia }\end{array}$ & {$[51]$} \\
\hline AP-1 decoy & $\begin{array}{l}\text { Oxidative stress-induced } \\
\text { proliferation } \\
\text { and MMPs in rat cardiac } \\
\text { fibroblasts }\end{array}$ & $\mathrm{AP}-1 \downarrow$ & - & ODN & Rat cardiac fibroblasts & $\begin{array}{l}\text { LipofectAMINE } \\
2000\end{array}$ & $\begin{array}{l}\text {-Inhibited } X X O \text {-induced CF } \\
\text { proliferation and MMP } \\
\text { gene expression }\end{array}$ & {$[52]$} \\
\hline
\end{tabular}


Table 1. Cont.

\begin{tabular}{|c|c|c|c|c|c|c|c|c|}
\hline $\begin{array}{l}\text { Decoy } \\
\text { Name }\end{array}$ & Type of CVD & $\begin{array}{c}\text { Target } \\
\text { Up/Down } \\
\uparrow \downarrow\end{array}$ & $\begin{array}{c}\text { Concentration/Dose } \\
\mu \mathrm{M} \\
\mathrm{mg} / \mathrm{kg} / \mathrm{day}\end{array}$ & Decoy Type & Model/Cell Line & Delivery Method & Results & Ref. \\
\hline CRE decoy & Intimal hyperplasia & $\mathrm{CRE} \downarrow$ & $7.814 \mathrm{pmol} / \mathrm{mL}$ & ODN & Mice & $\begin{array}{l}\text { ultrasound- } \\
\text { sonoporation }\end{array}$ & $\begin{array}{l}\text {-Decreased VSMC } \\
\text { proliferation and migration } \\
\text {-Suppressed the intimal } \\
\text { hyperplasia formation }\end{array}$ & {$[54]$} \\
\hline EGR-1 decoy & $\begin{array}{l}\text { Atherosclerosis and } \\
\text { restenosis }\end{array}$ & EGR-1 $\downarrow$ & $80 \mu \mathrm{M}$ & ODN & $\begin{array}{l}\text { Hypercholesterolemic } \\
\text { rabbits }\end{array}$ & - & $\begin{array}{l}\text {-The Egr-1 decoy reduced } \\
\text { inflammation, cell } \\
\text { proliferation and later } \\
\text { neointimal hyperplasia }\end{array}$ & [55] \\
\hline EGR-1 decoy & $\begin{array}{l}\text { Vein graft failure } \\
\text { intimal hyperplasia }\end{array}$ & EGR-1 $\downarrow$ & $500 \mu \mathrm{g}$ & ODN & Rabbits & $\begin{array}{l}\text { Fugene6 } \\
\text { transfection } \\
\text { reagent }\end{array}$ & $\begin{array}{c}\text {-Reduced VSMC } \\
\text { proliferation and intimal } \\
\text { hyperplasia }\end{array}$ & [56] \\
\hline EGR-1 decoy & Neointimal hyperplasia & EGR-1 $\downarrow$ & $0.1 \mu \mathrm{M}$ & ODN & $\begin{array}{l}\text { Balloon-injured rat } \\
\text { VSMCs }\end{array}$ & FuGene6 & $\begin{array}{c}\text {-Inhibited VSMC } \\
\text { proliferation and } \\
\text { neointimal hyperplasia }\end{array}$ & [57] \\
\hline E2F decoy & $\begin{array}{c}\text {-Carotid injury } \\
\text {-Abnormal growth of } \\
\text { vascular cells }\end{array}$ & $\mathrm{E} 2 \mathrm{~F} \downarrow$ & $3 \mu \mathrm{M}$ & ODN & $\begin{array}{l}\text {-Rat carotid injury } \\
\text {-Rat aortic VSMCs }\end{array}$ & HVJ liposomes & $\begin{array}{l}\text {-Inhibited proliferation of } \\
\text { SMC } \\
\text {-Inhibited formation of } \\
\text { vascular lesion }\end{array}$ & {$[60]$} \\
\hline E2F decoy & $\begin{array}{l}\text { Neointimal hyperplasia } \\
\text { and vein graft failure }\end{array}$ & $\mathrm{E} 2 \mathrm{~F} \downarrow$ & $\begin{array}{l}0.38 \mathrm{mg} / \mathrm{mL} \\
(40 \mu \mathrm{mol} / \mathrm{L})\end{array}$ & ODN & Human & $\begin{array}{l}\text { pressure- } \\
\text { mediated delivery } \\
\text { system }\end{array}$ & $\begin{array}{l}\text {-Edifoligide is no more } \\
\text { effective than placebo in } \\
\text { preventing of vein graft } \\
\text { Failure }\end{array}$ & [61] \\
\hline E2F decoy & $\begin{array}{c}\text { Atherosclerosis } \\
\text { neointimal thickness }\end{array}$ & $\begin{array}{l}\mathrm{E} 2 \mathrm{~F} \downarrow \\
\mathrm{PCNA} \downarrow\end{array}$ & $40 \mu \mathrm{mol} / \mathrm{L}$ & ODN & $\begin{array}{l}\text { Cholesterol-fed } \\
\text { rabbits }\end{array}$ & $\begin{array}{l}\text { nondistending } \\
\text { pressure- } \\
\text { mediated } \\
\text { transfection }\end{array}$ & $\begin{array}{l}\text {-Reduced neointimal } \\
\text { thickness } \\
\text {-Inhibited plaqe formation }\end{array}$ & [64] \\
\hline E2F decoy & $\begin{array}{l}\text { Atherosclerosis } \\
\text { graft failure }\end{array}$ & $\begin{array}{l}\mathrm{E} 2 \mathrm{~F} \downarrow \\
\mathrm{PCNA} \downarrow \\
\mathrm{c}-\mathrm{myc} \downarrow\end{array}$ & $40 \mu \mathrm{mol} / \mathrm{L}$ & ODN & Human & $\begin{array}{l}\text { pressure- } \\
\text { mediated DNA } \\
\text { transfection }\end{array}$ & -Decreased stenosis & [63] \\
\hline
\end{tabular}


Table 1. Cont.

\begin{tabular}{|c|c|c|c|c|c|c|c|c|}
\hline $\begin{array}{l}\text { Decoy } \\
\text { Name }\end{array}$ & Type of CVD & $\begin{array}{c}\text { Target } \\
\text { Up/Down } \\
\uparrow \downarrow\end{array}$ & $\begin{array}{c}\text { Concentration/Dose } \\
\mu \mathrm{M} \\
\mathrm{mg} / \mathrm{kg} / \text { day }\end{array}$ & Decoy Type & Model/Cell Line & Delivery Method & Results & Ref. \\
\hline E2F decoy & Atherosclerosis & $\mathrm{E} 2 \mathrm{~F} \downarrow$ & $40 \mu \mathrm{mol} / \mathrm{L}$ & ODN & Human & - & $\begin{array}{l}\text {-Reduced critical stenosis } \\
\text { and neointimal volume }\end{array}$ & [65] \\
\hline Edifoligide & Atherosclerosis & $\mathrm{E} 2 \mathrm{~F} \downarrow$ & $40 \mu \mathrm{mol} / \mathrm{L}$ & ODN & Human & - & $\begin{array}{c}\text {-Improvement in secondary } \\
\text { graft patency } \\
\text {-Did not showed any } \\
\text { protection against vein graft } \\
\text { failure }\end{array}$ & [66] \\
\hline E2F decoy & $\begin{array}{l}\text { Atherosclerosis } \\
\text { intimal hyperplasia }\end{array}$ & $\mathrm{E} 2 \mathrm{~F} \downarrow$ & $1 \mathrm{mg} /$ pig & ODN & Balloon-injured pig & hydrogel catheter & $\begin{array}{c}\text {-Reduced plaque area } \\
\text {-Increased luminal and total } \\
\text { vessel areas }\end{array}$ & [67] \\
\hline E2F decoy & $\begin{array}{c}\text { Neointimal formation } \\
\text { Cardiac Allograft } \\
\text { Arteriopathy }\end{array}$ & $\mathrm{E} 2 \mathrm{~F} \downarrow$ & & ODN & $\begin{array}{l}\text { Mice and Japanese } \\
\text { monkeys }\end{array}$ & $\mathrm{HVJ}$ & $\begin{array}{l}\text {-Suppressed neointimal } \\
\text { formation and prevented } \\
\text { expression of cell-cycle } \\
\text { regulatory genes } \\
\text {-Reduced Cardiac allograft } \\
\text { arteriopathy }\end{array}$ & [68] \\
\hline $\begin{array}{c}\text { chimeric } \\
\text { decoy }\end{array}$ & \multirow[b]{3}{*}{ Neointimal formation } & $\begin{array}{c}\mathrm{NF}-\kappa \mathrm{B} \downarrow \\
\mathrm{E} 2 \mathrm{~F} \downarrow\end{array}$ & $200 \mathrm{nM}$ & \multirow[b]{3}{*}{ ODN } & \multirow[b]{3}{*}{$\begin{array}{l}\text { Cholesterol-fed } \\
\text { rabbits }\end{array}$} & \multirow[b]{3}{*}{-} & $\begin{array}{l}\text {-Suppressed anastomotic } \\
\text { intimal hyperplasia }\end{array}$ & \multirow[b]{3}{*}{ [72] } \\
\hline NF- $\kappa B$ decoy & & NF-B $\downarrow$ & $600 \mathrm{nM}$ & & & & -accelerated re & \\
\hline E2F decoy & & $\mathrm{E} 2 \mathrm{~F} \downarrow$ & $600 \mathrm{nM}$ & & & & $\begin{array}{l}\text {-Inhibited macrophage } \\
\text { accumulation } \\
\text {-Repressed the expression of } \\
\text { VCAM-1 and MCP-1 gene } \\
\text {-Inhibited VSMC } \\
\text { proliferation } \\
\text { Chimeric decoy was more } \\
\text { than two others. }\end{array}$ & \\
\hline
\end{tabular}


Table 1. Cont.

\begin{tabular}{|c|c|c|c|c|c|c|c|c|}
\hline $\begin{array}{l}\text { Decoy } \\
\text { Name }\end{array}$ & Type of CVD & $\begin{array}{c}\text { Target } \\
\text { Up/Down } \\
\uparrow \downarrow\end{array}$ & $\begin{array}{c}\text { Concentration/Dose } \\
\mu \mathrm{M} \\
\mathrm{mg} / \mathrm{kg} / \text { day }\end{array}$ & Decoy Type & Model/Cell Line & Delivery Method & Results & Ref. \\
\hline NF- $\kappa B$ decoy & $\begin{array}{l}\text { Remodeling of vascular } \\
\text { neointimal formation } \\
\text { restenosis }\end{array}$ & $N F-\kappa B \downarrow$ & $1 \mathrm{mg}$ & ODN & Human & remedy catheter & $\begin{array}{l}\text {-Suppressed the } \\
\text { development of neointimal } \\
\text { formation } \\
\text {-reduced lesion }\end{array}$ & {$[70]$} \\
\hline NF-kB decoy & Atherosclerosis & NF-kB $\downarrow$ & $0.4 \mathrm{mg} / \mathrm{kg}$ & ODN & LPS/Fat-induced mice & - & $\begin{array}{c}\text {-Decreased } \\
\text { pro-inflammatory cytokines } \\
\text { and inflammatory markers, } \\
\text { VCAM-1 and ICAM-1 }\end{array}$ & [73] \\
\hline $\begin{array}{l}\text { Chimeric } \\
\text { decoy }\end{array}$ & Atherosclerosis & $\begin{array}{c}\mathrm{NF}-\kappa \mathrm{B} \downarrow \\
\mathrm{Sp} 1 \downarrow\end{array}$ & $10 \mu \mathrm{g}$ per mouse & ODN & $\begin{array}{l}\text { LPS/atherogenic } \\
\text { diet-induced mice }\end{array}$ & - & $\begin{array}{c}\text {-Decreased TG and TC } \\
\text {-improved atherosclerotic } \\
\text { changes }\end{array}$ & {$[74]$} \\
\hline NF- $\kappa B$ decoy & $\begin{array}{l}\text { Neointimal hyperplasia } \\
\text { Atherosclerosis }\end{array}$ & $N F-\kappa B \downarrow$ & $40 \mu \mathrm{mol} / 1$ & ODN & $\begin{array}{c}\text { Hypercholesterolemic } \\
\text { rabbits }\end{array}$ & $\begin{array}{l}\text { pressure- } \\
\text { mediated } \\
\text { transfection }\end{array}$ & $\begin{array}{c}\text {-Inhibited the development } \\
\text { of neointimal hyperplasia } \\
\text {-Suppressed inflammatory } \\
\text { changes and accumulation } \\
\text { of VSMC }\end{array}$ & [75] \\
\hline $\begin{array}{c}\text { NF-кB } \\
\text { decoys } \\
\text { (NF-ICAM, } \\
\text { NF-VCAM, } \\
\text { NF-ESEL) }\end{array}$ & $\begin{array}{c}\text { Graft coronary artery } \\
\text { disease (GCAD) }\end{array}$ & $\begin{array}{l}\text { NF- } \mathrm{B} \text { } \downarrow \\
\mathrm{ICAM} \downarrow \\
\mathrm{VCAM} \downarrow \\
\mathrm{ESEL} \downarrow\end{array}$ & $160 \mu \mathrm{mol} / \mathrm{L}$ & ODN & Rat & $\begin{array}{l}\text { pressure- } \\
\text { mediated }\end{array}$ & $\begin{array}{l}\text {-Blocked adhesion molcule } \\
\text { expression and reperfusion } \\
\text { injury } \\
\text {-Prolongs allograft survival } \\
\text { and decreases GCAD }\end{array}$ & [76] \\
\hline NF-kB decoy & $\begin{array}{c}\text { Restenosis } \\
\text { Neointimal Formation } \\
\text { neointimal hyperplasia }\end{array}$ & NF-kB $\downarrow$ & - & ODN & Rabbits & $\begin{array}{l}\text { chitosan-modifed } \\
\text { PLGA NS }\end{array}$ & $\begin{array}{c}\text {-Inhibited neointimal } \\
\text { formation } \\
\text {-Restored ECMs } \\
\text {-Inhibited macrophage } \\
\text { recruitment } \\
\text {-Inhibited VSMCs growth }\end{array}$ & [77] \\
\hline NF- $\kappa$ B decoy & $\begin{array}{l}\text { Inflammation in } \\
\text { atherosclerotic }\end{array}$ & $\mathrm{NF}-\kappa \mathrm{B} \downarrow$ & $2 \mu \mathrm{mol} / 1$ & ODN & $\begin{array}{c}\text { Mouse brain } \\
\text { microvascular } \\
\text { endothelial cells }\end{array}$ & cationic liposome & $\begin{array}{l}\text {-Inhibited TNF-induced } \\
\text { expression of interleukin-6 } \\
\text { and } \\
\text { ICAM-1 in endothelial cells }\end{array}$ & [78] \\
\hline
\end{tabular}


Table 1. Cont.

\begin{tabular}{|c|c|c|c|c|c|c|c|c|}
\hline $\begin{array}{l}\text { Decoy } \\
\text { Name }\end{array}$ & Type of CVD & $\begin{array}{c}\text { Target } \\
\text { Up/Down } \\
\uparrow \downarrow\end{array}$ & $\begin{array}{c}\text { Concentration/Dose } \\
\mu \mathrm{M} \\
\mathrm{mg} / \mathrm{kg} / \text { day }\end{array}$ & Decoy Type & Model/Cell Line & Delivery Method & Results & Ref. \\
\hline $\begin{array}{l}\text { NF-kB } \\
\text { Decoy }\end{array}$ & Neointimal Formation & $\mathrm{NF}-\kappa \mathrm{B} \downarrow$ & $20 \mu \mathrm{g}$ & ODN & Arterial injured mice & $\begin{array}{l}\text { ultrasound- } \\
\text { microbubble- } \\
\text { mediated }\end{array}$ & $\begin{array}{l}\text {-Reduced the } \\
\text { neointima/media areas. } \\
\text { The expression of } \\
\text { inflammatory factors }\end{array}$ & [33] \\
\hline R-ODN & Cardiovascular diseases & $N F-\kappa B \downarrow$ & $10 \mathrm{nM}$ & ODN & VSMC & lipofectamine & $\begin{array}{l}\text {-Expression of MMP-9 and } \\
\text { the proliferation of VSMC } \\
\text { were inhibited }\end{array}$ & {$[71]$} \\
\hline NF- $\kappa$ B decoy & $\begin{array}{l}\text { Atherosclerosis } \\
\text { /lesion formation } \\
\text { after vascular injury/ } \\
\text { intimal hyperplasia }\end{array}$ & $N F-\kappa B \downarrow$ & $15 \mu \mathrm{M}$ & ODN & $\begin{array}{c}\text { Balloon-injured } \\
\text { rat }\end{array}$ & HVJ-liposome & $\begin{array}{c}\text {-Apoptosis was } \\
\text { upregulated } \\
\text {-ICAM-1 and VCAM-1 } \\
\text { expression was decreased } \\
\text {-The migration of } \\
\text { T-lymphocytes and } \\
\text { macrophages into the } \\
\text { media and neointima was } \\
\text { inhibited }\end{array}$ & [79] \\
\hline NF- $\kappa$ B decoy & $\begin{array}{l}\text { Intimal hyperplasia } \\
\text { neointimal formation }\end{array}$ & $N F-\kappa B \downarrow$ & $1 \mathrm{mg} / \mathrm{pig}$ & ODN & $\begin{array}{l}\text { Balloon-injured } \\
\text { pigs }\end{array}$ & $\begin{array}{l}\text { hydrogel balloon } \\
\text { catheter }\end{array}$ & $\begin{array}{c}\text {-Decoy inhibited the } \\
\text { proliferation of VSMC- } \\
\text { Reduced the neointimal } \\
\text { area } \\
\text {-Decrease the expression of } \\
\text { ICAM }\end{array}$ & [80] \\
\hline Smad decoy & Atherosclerosis & $\begin{array}{c}\text { TGF- } \beta 1 \downarrow \\
\text { PAI- } 1 \downarrow \\
\alpha \text {-SMA } \downarrow\end{array}$ & - & ODN & $\begin{array}{l}\text { Shear stress-induced } \\
\text { ApoE-/-mice }\end{array}$ & $\begin{array}{l}\text { Trans IT In vivo } \\
\text { Gene Delivery } \\
\text { System }\end{array}$ & $\begin{array}{l}\text {-Suppressed the histological } \\
\text { atherosclerotic changes } \\
\text {-Prevented the extracellular } \\
\text { matrix deposition }\end{array}$ & [81] \\
\hline $\begin{array}{c}\text { DcR3 } \\
\text { (Biomarker) }\end{array}$ & Atherosclerosis & - & - & Peptide & Human & - & $\begin{array}{c}\text {-Circulating levels of DcR3 } \\
\text { in CAD patients require } \\
\text { coronary artery bypass } \\
\text { grafting are high }\end{array}$ & [83] \\
\hline
\end{tabular}


Table 1. Cont.

\begin{tabular}{|c|c|c|c|c|c|c|c|c|}
\hline $\begin{array}{l}\text { Decoy } \\
\text { Name }\end{array}$ & Type of CVD & $\begin{array}{c}\text { Target } \\
\text { Up/Down } \\
\uparrow \downarrow\end{array}$ & $\begin{array}{c}\text { Concentration/Dose } \\
\mu \mathrm{M} \\
\mathrm{mg} / \mathrm{kg} / \mathrm{day} \\
\end{array}$ & Decoy Type & Model/Cell Line & Delivery Method & Results & Ref. \\
\hline $\begin{array}{c}\text { DcR3 } \\
\text { (Biomarker) }\end{array}$ & $\begin{array}{c}\text { Coronary Artery Disease } \\
\text { Severity }\end{array}$ & & & Peptide & & & $\begin{array}{l}\text {-Increased level of } \\
\text { circulating DcR3 are } \\
\text { associated with CAD } \\
\text { severity and predict future } \\
\text { MACE in patients with } \\
\text { multivessel CAD }\end{array}$ & [84] \\
\hline SREBP decoy & Atherosclerosis & $\begin{array}{c}\text { SREBP-1c } \downarrow \text { FAS, } \\
\text { SCD- } 1 \downarrow \\
\text { ACC } 1 \downarrow \\
\text { HMGCR } \downarrow\end{array}$ & $\begin{array}{c}10 \mu \mathrm{g} \\
\text { every two weeks for } \\
12 \text { weeks }\end{array}$ & ODN & $\begin{array}{c}\text { High-fat diet fed } \\
\text { hyperlipidemic mice }\end{array}$ & - & $\begin{array}{c}\text {-Regulated lipid } \\
\text { metabolism and inhibited } \\
\text { lipogenesis } \\
\text {-Decreased } \\
\text { pro-inflammatory cytokines }\end{array}$ & [85] \\
\hline
\end{tabular}


Author Contributions: Conceptualization, A.S. and M.M.-T.; writing—original draft preparation, M.M.-T. and A.S.; writing—review and editing, Y.T., A.J., S.H.A.-B., A.M.M.; supervision, A.S.; All authors have read and agreed to the published version of the manuscript.

Funding: This project was supported by the Russian Science Foundation (Grant \# 20-15-00264).

Institutional Review Board Statement: Not applicable.

Informed Consent Statement: Not applicable.

Data Availability Statement: Not applicable.

Conflicts of Interest: The authors declare no conflict of interest.

\section{References}

1. Bertrand, M.J.; Tardif, J.C. Inflammation and beyond: New directions and emerging drugs for treating atherosclerosis. Expert Opin. Emerg. Drugs 2017, 22, 1-26. [CrossRef] [PubMed]

2. Flores-Gomez, D.; Bekkering, S.; Netea, M.G.; Riksen, N.P. Trained Immunity in Atherosclerotic Cardiovascular Disease. Arterioscler. Thromb. Vasc. Biol. 2021, 41, 62-69. [CrossRef] [PubMed]

3. Kypreos, K.E.; Bitzur, R.; Karavia, E.A.; Xepapadaki, E.; Panayiotakopoulos, G.; Constantinou, C. Pharmacological Management of Dyslipidemia in Atherosclerosis: Limitations, Challenges, and New Therapeutic Opportunities. Angiology 2019, 70, 197-209. [CrossRef] [PubMed]

4. Durmaz, E.; Ikitimur, B.; Karadag, B.; Barman, H.A.; Atici, A.; Koca, D.; Raimoglu, U.; Karaca, O.F.; Mutlu, D.; Ongen, Z. The impact of atherosclerotic risk factors on disease progression in patients with previously diagnosed nonobstructive coronary artery disease: Factors affecting coronary artery disease progression. Coron. Artery Dis. 2020, 31, 365-371. [CrossRef]

5. Amarenco, P.; Hobeanu, C.; Labreuche, J.; Charles, H.; Giroud, M.; Meseguer, E.; Lavallée, P.C.; Gabriel Steg, P.; Vicaut, É.; Bruckert, E. Carotid atherosclerosis evolution when targeting a low-density lipoprotein cholesterol concentration $<70 \mathrm{mg} / \mathrm{dL}$ after an ischemic stroke of atherosclerotic origin. Circulation 2020, 142, 748-757. [CrossRef]

6. Battaglini, D.; Robba, C.; Lopes da Silva, A.; dos Santos Samary, C.; Leme Silva, P.; Dal Pizzol, F.; Pelosi, P.; Rocco, P.R.M. Brain-heart interaction after acute ischemic stroke. Crit. Care 2020, 24, 1-12. [CrossRef]

7. Whelton, S.P.; Deal, J.A.; Zikusoka, M.; Jacobson, L.P.; Sarkar, S.; Palella, F.J., Jr.; Kingsley, L.; Budoff, M.; Witt, M.D.; Brown, T.T. Associations between lipids and subclinical coronary atherosclerosis. Aids 2019, 33, 1053-1061. [CrossRef]

8. Henning, R.J. Recognition and treatment of ischemic heart diseases in women. Future Cardiol. 2019, 15, 197-225. [CrossRef]

9. Gupta, M.; Blumenthal, C.; Chatterjee, S.; Bandyopadhyay, D.; Jain, V.; Lavie, C.J.; Virani, S.S.; Ray, K.K.; Aronow, W.S.; Ghosh, R.K. Novel emerging therapies in atherosclerosis targeting lipid metabolism. Expert Opin. Investig. Drugs 2020, $29,611-622$. [CrossRef]

10. Afshari, A.R.; Mollazadeh, H.; Henney, N.C.; Jamialahmad, T.; Sahebkar, A. Effects of statins on brain tumors: A review. Semin. Cancer Biol. 2020. [CrossRef]

11. Bagheri, H.; Ghasemi, F.; Barreto, G.E.; Sathyapalan, T.; Jamialahmadi, T.; Sahebkar, A. The effects of statins on microglial cells to protect against neurodegenerative disorders: A mechanistic review. BioFactors 2020, 46, 309-325. [CrossRef]

12. Reiner, Ž.; Hatamipour, M.; Banach, M.; Pirro, M.; Al-Rasadi, K.; Jamialahmadi, T.; Radenkovic, D.; Montecucco, F.; Sahebkar, A. Statins and the Covid-19 main protease: In silico evidence on direct interaction. Arch. Med. Sci. 2020, 16, 490-496. [CrossRef]

13. Sahebkar, A.; Serban, C.; Ursoniu, S.; Mikhailidis, D.P.; Undas, A.; Lip, G.Y.H.; Bittner, V.; Ray, K.K.; Watts, G.F.; Kees Hovingh, G.; et al. The impact of statin therapy on plasma levels of von Willebrand factor antigen: Systematic review and meta-analysis of Randomised placebo-controlled trials. Thromb. Haemost. 2016, 115, 520-532. [CrossRef]

14. Banach, M.; Penson, P.E. Lipid-lowering therapies: Better together. Atherosclerosis 2021, 320, 86-88. [CrossRef]

15. Libby, P.; Everett, B.M. Novel antiatherosclerotic therapies. Arterioscler. Thromb. Vasc. Biol. 2019, 39, 538-545. [CrossRef]

16. Stojanović, S.D.; Fiedler, J.; Bauersachs, J.; Thum, T.; Sedding, D.G. Senescence-induced inflammation: An important player and key therapeutic target in atherosclerosis. Eur. Heart J. 2020, 41, 2983-2996. [CrossRef]

17. Lordan, R.; Tsoupras, A.; Zabetakis, I. Platelet activation and prothrombotic mediators at the nexus of inflammation and atherosclerosis: Potential role of antiplatelet agents. Blood Rev. 2020, 100694. [CrossRef] [PubMed]

18. Nettersheim, F.S.; De Vore, L.; Winkels, H. Vaccination in Atherosclerosis. Cells 2020, 9, 2560. [CrossRef]

19. Chyu, K.-Y.; Shah, P.K. In Pursuit of an Atherosclerosis Vaccine. Circ. Res. 2018, 123, 1121-1123. [CrossRef]

20. Ito, M.K.; Watts, G.F. Challenges in the Diagnosis and Treatment of Homozygous Familial Hypercholesterolemia. Drugs 2015, 75, 1715-1724. [CrossRef]

21. Naci, H.; Brugts, J.; Ades, T. Comparative tolerability and harms of individual statins: A study-level network meta-analysis of 246 955 participants from 135 randomized, controlled trials. Circ. Cardiovasc. Qual. Outcomes 2013, 6, 390-399. [CrossRef] [PubMed]

22. Bellosta, S.; Corsini, A. Statin drug interactions and related adverse reactions: An update. Expert Opin. Drug Saf. 2018, 17, 25-37. [CrossRef] [PubMed]

23. Bellosta, S.; Corsini, A. Statin drug interactions and related adverse reactions. Expert Opin. Drug Saf. 2012, 11, 933-946. [CrossRef] 
24. Landmesser, U.; Poller, W.; Tsimikas, S.; Most, P.; Paneni, F.; Lüscher, T.F. From traditional pharmacological towards nucleic acid-based therapies for cardiovascular diseases. Eur. Heart J. 2020, 41, 3884-3899. [CrossRef]

25. Mäkinen, P.; Ruotsalainen, A.-K.; Ylä-Herttuala, S. Nucleic acid-based therapies for atherosclerosis. Curr. Atheroscler. Rep. 2020, 22, 1-8. [CrossRef]

26. Vahdat Lasemi, F.; Mahjoubin-Tehran, M.; Aghaee-Bakhtiari, S.H.; Jalili, A.; Jaafari, M.R.; Sahebkar, A. Harnessing nucleic acid-based therapeutics for atherosclerotic cardiovascular disease: State of the art. Drug Discov. Today 2019, 24, 1116-1131. [CrossRef]

27. Hecker, M.; Wagner, A.H. Transcription factor decoy technology: A therapeutic update. Biochem. Pharmacol. 2017, 144, 29-34. [CrossRef]

28. Gambari, R. New trends in the development of transcription factor decoy (TFD) pharmacotherapy. Curr. Drug Targets 2004, 5, 419-430. [CrossRef]

29. Crinelli, R.; Bianchi, M.; Gentilini, L.; Palma, L.; Magnani, M. Locked nucleic acids (LNA): Versatile tools for designing oligonucleotide decoys with high stability and affinity. Curr. Drug Targets 2004, 5, 745-752. [CrossRef]

30. Farahmand, L.; Darvishi, B.; Majidzadeh, A.K. Suppression of chronic inflammation with engineered nanomaterials delivering nuclear factor кB transcription factor decoy oligodeoxynucleotides. Drug Deliv. 2017, 24, 1249-1261. [CrossRef]

31. Rad, S.M.A.H.; Langroudi, L.; Kouhkan, F.; Yazdani, L.; Koupaee, A.N.; Asgharpour, S.; Shojaei, Z.; Bamdad, T.; Arefian, E. Transcription factor decoy: A pre-transcriptional approach for gene downregulation purpose in cancer. Tumor Biol. 2015, 36, 4871-4881. [CrossRef] [PubMed]

32. Mahjoubin-Tehran, M.; Rezaei, S.; Jalili, A.; Aghaee-Bakhtiari, S.H.; Sahebkar, A. Decoy oligodeoxynucleotide technology: An emerging paradigm for breast cancer treatment. Drug Discov. Today 2020, 25, 195-200. [CrossRef] [PubMed]

33. Inagaki, H.; Suzuki, J.I.; Ogawa, M.; Taniyama, Y.; Morishita, R.; Isobe, M. Ultrasound-microbubble-mediated NF-кB decoy transfection attenuates neointimal formation after arterial injury in mice. J. Vasc. Res. 2005, 43, 12-18. [CrossRef]

34. Mahjoubin-Tehran, M.; Rezaei, S.; Jalili, A.; Aghaee-Bakhtiari, S.H.; Orafai, H.M.; Jamialahmadi, T.; Sahebkar, A. Peptide decoys: A new technology offering therapeutic opportunities for breast cancer. Drug Discov. Today 2020, 25, 593-598. [CrossRef]

35. Mantovani, A.; Locati, M.; Vecchi, A.; Sozzani, S.; Allavena, P. Decoy receptors: A strategy to regulate inflammatory cytokines and chemokines. Trends Immunol. 2001, 22, 328-336. [CrossRef]

36. Jimeno, A.; Gordon, M.; Chugh, R.; Messersmith, W.; Mendelson, D.; Dupont, J.; Stagg, R.; Kapoun, A.M.; Xu, L.; Uttamsingh, S. A first-in-human phase I study of the anticancer stem cell agent ipafricept (OMP-54F28), a decoy receptor for Wnt ligands, in patients with advanced solid tumors. Clin. Cancer Res. 2017, 23, 7490-7497. [CrossRef]

37. Chandra, N.; Frängsmyr, L.; Arnberg, N. Decoy receptor interactions as novel drug targets against EKC-causing human adenovirus. Viruses 2019, 11, 242. [CrossRef]

38. Lillehoj, E.P.; Guang, W.; Hyun, S.W.; Liu, A.; Hegerle, N.; Simon, R.; Cross, A.S.; Ishida, H.; Luzina, I.G.; Atamas, S.P. Neuraminidase 1-mediated desialylation of the mucin 1 ectodomain releases a decoy receptor that protects against Pseudomonas aeruginosa lung infection. J. Biol. Chem. 2019, 294, 662-678. [CrossRef]

39. Albulescu, L.-O.; Kazandjian, T.; Slagboom, J.; Bruyneel, B.; Ainsworth, S.; Alsolaiss, J.; Wagstaff, S.C.; Whiteley, G.; Harrison, R.A.; Ulens, C. A decoy-receptor approach using nicotinic acetylcholine receptor mimics reveals their potential as novel therapeutics against neurotoxic snakebite. Front. Pharmacol. 2019, 10, 848. [CrossRef]

40. Chakrabarty, P.; Li, A.; Ladd, T.B.; Strickland, M.R.; Koller, E.J.; Burgess, J.D.; Funk, C.C.; Cruz, P.E.; Allen, M.; Yaroshenko, M. TLR5 decoy receptor as a novel anti-amyloid therapeutic for Alzheimer's disease. J. Exp. Med. 2018, 215, 2247-2264. [CrossRef]

41. Vallot, O.; Combettes, L.; Jourdon, P.; Inamo, J.; Marty, I.; Claret, M.; Lompré, A.M. Intracellular Ca(2+) handling in vascular smooth muscle cells is affected by proliferation. Arterioscler. Thromb. Vasc. Biol. 2000, 20, 1225-1235. [CrossRef] [PubMed]

42. Lipskaia, L.; del Monte, F.; Capiod, T.; Yacoubi, S.; Hadri, L.; Hours, M.; Hajjar, R.J.; Lompré, A.M. Sarco/endoplasmic reticulum Ca2+-ATPase gene transfer reduces vascular smooth muscle cell proliferation and neointima formation in the rat. Circ. Res. 2005, 97, 488-495. [CrossRef] [PubMed]

43. Steenaart, N.A.; Ganim, J.R.; Di Salvo, J.; Kranias, E.G. The phospholamban phosphatase associated with cardiac sarcoplasmic reticulum is a type 1 enzyme. Arch. Biochem. Biophys. 1992, 293, 17-24. [CrossRef]

44. Jang, S.P.; Oh, J.G.; Kang, D.H.; Kang, J.Y.; Kang, S.W.; Hajjar, R.J.; Park, W.J. A decoy peptide targeted to protein phosphatase 1 attenuates degradation of serca2a in vascular smooth muscle cells. PLoS ONE 2016, 11, e0165569. [CrossRef]

45. Laukkanen, J.; Lehtolainen, P.; Gough, P.J.; Greaves, D.R.; Gordon, S.; Ylä-Herttuala, S. Adenovirus-mediated gene transfer of a secreted form of human macrophage scavenger receptor inhibits modified low-density lipoprotein degradation and foam-cell formation in macrophages. Circulation 2000, 101, 1091-1096. [CrossRef]

46. Jalkanen, J.; Leppänen, P.; Pajusola, K.; Närvänen, O.; Mähönen, A.; Vähäkangas, E.; Greaves, D.R.; Büeler, H.; Ylä-Herttuala, S. Adeno-associated virus-mediated gene transfer of a secreted decoy human macrophage scavenger receptor reduces atherosclerotic lesion formation in LDL receptor knockout mice. Mol. Ther. 2003, 8, 903-910. [CrossRef]

47. Jalkanen, J.; Leppänen, P.; Närvänen, O.; Greaves, D.R.; Ylä-Herttuala, S. Adenovirus-mediated gene transfer of a secreted decoy human macrophage scavenger receptor (SR-AI) in LDL receptor knock-out mice. Atherosclerosis 2003, 169, 95-103. [CrossRef]

48. Kume, M.; Komori, K.; Matsumoto, T.; Onohara, T.; Takeuchi, K.; Yonemitsu, Y.; Sugimachi, K. Administration of a decoy against the activator protein-1 binding site suppresses neointimal thickening in rabbit balloon-injured arteries. Circulation 2002, 105, 1226-1232. [CrossRef] 
49. Nikol, S.; Isner, J.M.; Pickering, J.G.; Kearney, M.; Leclerc, G.; Weir, L. Expression of transforming growth factor-beta 1 is increased in human vascular restenosis lesions. J. Clin. Investig. 1992, 90, 1582-1592. [CrossRef]

50. Ahn, J.D.; Morishita, R.; Kaneda, Y.; Lee, S.J.; Kwon, K.Y.; Choi, S.Y.; Lee, K.U.; Park, J.Y.; Moon, I.J.; Park, J.G.; et al. Inhibitory effects of novel AP-1 decoy oligodeoxynucleotides on vascular smooth muscle cell proliferation in vitro and neointimal formation in vivo. Circ. Res. 2002, 90, 1325-1332. [CrossRef]

51. Cho, W.H.; Kim, H.T.; Koo, J.H.; Lee, I.K. Effect of AP-1 Decoy Using Hemagglutinating Virus of Japan-Liposome on the Intimal Hyperplasia of the Autogenous Vein Graft in Mongrel Dogs. Transplant. Proc. 2006, 38, 2161-2163. [CrossRef]

52. Xie, S.; Nie, R.; Wang, J.; Li, F.; Yuan, W. Transcription factor decoys for activator protein-1 (AP-1) inhibit oxidative stress-induced proliferation and matrix metalloproteinases in rat cardiac fibroblasts. Transl. Res. 2009, 153, 17-23. [CrossRef]

53. Nakanishi, K.; Saito, Y.; Azuma, N.; Sasajima, T. Cyclic adenosine monophosphate response-element binding protein activation by mitogen-activated protein kinase-activated protein kinase 3 and four-and-a-half LIM domains 5 plays a key role for vein graft intimal hyperplasia. J. Vasc. Surg. 2013, 57, 182-193.e110. [CrossRef]

54. Uchida, D.; Saito, Y.; Kikuchi, S.; Yoshida, Y.; Hirata, S.; Sasajima, T.; Azuma, N. Development of gene therapy with a cyclic adenosine monophosphate response element decoy oligodeoxynucleotide to prevent vascular intimal hyperplasia. J. Vasc. Surg. 2010, 71, 229-241. [CrossRef]

55. Ohtani, K.; Egashira, K.; Usui, M.; Ishibashi, M.; Hiasa, K.I.; Zhao, Q.; Aoki, M.; Kaneda, Y.; Morishita, R.; Takeshita, A. Inhibition of neointimal hyperplasia after balloon injury by cis-element 'decoy' of early growth response gene-1 in hypercholesterolemic rabbits. Gene Ther. 2004, 11, 126-132. [CrossRef]

56. Wang, X.; Mei, Y.; Ji, Q.; Feng, J.; Cai, J.; Xie, S. Early growth response gene-1 decoy oligonucleotides inhibit vascular smooth muscle cell proliferation and neointimal hyperplasia of autogenous vein graft in rabbits. Interact. Cardiovasc. Thorac. Surg. 2015, 21, 50-54. [CrossRef]

57. Han, W.; Liu, G.N. EGR-1 decoy ODNs inhibit vascular smooth muscle cell proliferation and neointimal hyperplasia of ballooninjured arteries in rat. Life Sci. 2010, 86, 234-243. [CrossRef]

58. Peroulis, M.; Kakisis, J.; Kapelouzou, A.; Giagini, A.; Giaglis, S.; Mantziaras, G.; Kostomitsopoulos, N.; Karayannacos, P.; MacHeras, A. The Role of ex-vivo Gene Therapy of Vein Grafts with Egr-1 Decoy in the Suppression of Intimal Hyperplasia. Eur. J. Vasc. Endovasc. Surg. 2010, 40, 216-223. [CrossRef]

59. Ding, X.; Yao, W.; Zhu, J.; Mu, K.; Zhang, J.; Zhang, J.-A. Resveratrol Attenuates High Glucose-Induced Vascular Endothelial Cell Injury by Activating the E2F3 Pathway. BioMed. Res. Int. 2020, 2020. [CrossRef]

60. Morishita, R.; Gibbons, G.H.; Horiuchi, M.; Ellison, K.E.; Nakajima, M.; Zhang, L.; Kaneda, Y.; Ogihara, T.; Dzau, V.J. A gene therapy strategy using a transcription factor decoy of the E2F binding site inhibits smooth muscle proliferation in vivo. Proc. Natl. Acad. Sci. USA 1995, 92, 5855-5859. [CrossRef]

61. Alexander, J.H.; Hafley, G.; Harrington, R.A.; Peterson, E.D.; Ferguson, T.B., Jr.; Lorenz, T.J.; Goyal, A.; Gibson, M.; Mack, M.J.; Gennevois, D.; et al. Efficacy and safety of edifoligide, an E2F transcription factor decoy, for prevention of vein graft failure following coronary artery bypass graft surgery: PREVENT IV: A randomized controlled trial. J. Am. Med. Assoc. 2005, 294, 2446-2454. [CrossRef]

62. Lopes, R.D.; Williams, J.B.; Mehta, R.H.; Reyes, E.M.; Hafley, G.E.; Allen, K.B.; MacK, M.J.; Peterson, E.D.; Harrington, R.A.; Gibson, C.M.; et al. Edifoligide and long-term outcomes after coronary artery bypass grafting: PRoject of Ex-vivo Vein graft ENgineering via Transfection IV (PREVENT IV) 5-year results. Am. Heart J. 2012, 164, 379-386.e371. [CrossRef] [PubMed]

63. Mann, M.J.; Whittemore, A.D.; Donaldson, M.C.; Belkin, M.; Conte, M.S.; Polak, J.F.; Orav, E.J.; Ehsan, A.; Dell'Acqua, G.; Dzau, V.J. Ex-vivo gene therapy of human vascular bypass grafts with E2F decoy: The PREVENT single-centre, randomised, controlled trial. Lancet 1999, 354, 1493-1498. [CrossRef]

64. Ehsan, A.; Mann, M.J.; Dell'Acqua, G.; Dzau, V.J. Long-term stabilization of vein graft wall architecture and prolonged resistance to experimental atherosclerosis after E2F decoy oligonucleotide gene therapy. J. Thorac. Cardiovasc. Surg. 2001, 121, 714-722. [CrossRef]

65. Grube, E.; Felderhoff, T.; Fitzgerald, P.; Terashima, M.; Gerckens, U.; Orav, E.; Lorenz, T.; Iversen, S. Phase II trial of the E2F decoy in coronary bypass grafting. In Proceedings of the American Heart Association Annual Meeting (Late Breaking Clinical Trials), Anaheim, CA, USA, 12 November 2001.

66. Conte, M.S.; Bandyk, D.F.; Clowes, A.W.; Moneta, G.L.; Seely, L.; Lorenz, T.J.; Namini, H.; Hamdan, A.D.; Roddy, S.P.; Belkin, M.; et al. Results of PREVENT III: A multicenter, randomized trial of edifoligide for the prevention of vein graft failure in lower extremity bypass surgery. J. Vasc. Surg. 2006, 43, 742-751. [CrossRef]

67. Nakamura, T.; Morishita, R.; Asai, T.; Tsuboniwa, N.; Aoki, M.; Sakonjo, H.; Yamasaki, K.; Hashiya, N.; Kaneda, Y.; Ogihara, T. Molecular strategy using cis-element 'decoy' of E2F binding site inhibits neointimal formation in porcine balloon-injured coronary artery model. Gene Ther. 2002, 9, 488-494. [CrossRef]

68. Kawauchi, M.; Suzuki, J.I.; Morishita, R.; Wada, Y.; Izawa, A.; Tomita, N.; Amano, J.; Kaneda, Y.; Ogihara, T.; Takamoto, S.; et al. Gene therapy for attenuating cardiac allograft arteriopathy using ex vivo E2F decoy transfection by HVJ-AVE-liposome method in mice and nonhuman primates. Circ. Res. 2000, 87, 1063-1068. [CrossRef] 
69. Lin, Y.-T.; Chen, L.-K.; Jian, D.-Y.; Hsu, T.-C.; Huang, W.-C.; Kuan, T.-T.; Wu, S.-Y.; Kwok, C.-F.; Ho, L.-T.; Juan, C.-C. Visfatin Promotes Monocyte Adhesion by Upregulating ICAM-1 and VCAM-1 Expression in Endothelial Cells via Activation of p38PI3K-Akt Signaling and Subsequent ROS Production and IKK/NF-kB Activation. Cell. Physiol. Biochem. Int. J. Exp. Cell. Physiol. Biochem. Pharmacol. 2019, 52, 1398-1411.

70. Suzuki, J.; Tezuka, D.; Morishita, R.; Isobe, M. Eight-year follow-up of an initial case with NF-kB decoy oligodeoxynucleotide transfection after coronary stent implantation. Immunol. Endocr. Metab. Agents Med. Chem. 2012, 12, 40-42. [CrossRef]

71. Osako, M.K.; Tomita, N.; Nakagami, H.; Kunugiza, Y.; Yoshino, M.; Yuyama, K.; Tomita, T.; Yoshikawa, H.; Ogihara, T.; Morishita, R. Increase in nuclease resistance and incorporation of NF- $\mathrm{kB}$ decoy oligodeoxynucleotides by modification of the $3^{\prime}$-terminus. $J$. Gene Med. 2007, 9, 812-819. [CrossRef]

72. Miyake, T.; Aoki, M.; Morishita, R. Inhibition of anastomotic intimal hyperplasia using a chimeric decoy strategy against NFkB and E2F in a rabbit model. Cardiovasc. Res. 2008, 79, 706-714. [CrossRef]

73. Kim, S.J.; Park, J.H.; Kim, K.H.; Lee, W.R.; Lee, S.; Kwon, O.C.; Kim, K.S.; Park, K.K. Effect of NF-kB decoy oligodeoxynucleotide on LPS/high-fat diet-induced atherosclerosis in an animal model. Basic Clin. Pharmacol. Toxicol. 2010, 107, 925-930. [CrossRef]

74. Lee, W.R.; Kim, K.H.; An, H.J.; Park, Y.Y.; Kim, K.S.; Lee, C.K.; Min, B.K.; Park, K.K. Effects of Chimeric Decoy Oligodeoxynucleotide in the Regulation of Transcription Factors NF- $\mathrm{BB}$ and Sp1 in an Animal Model of Atherosclerosis. Basic Clin. Pharmacol. Toxicol. 2013, 112, 236-243. [CrossRef]

75. Miyake, T.; Aoki, M.; Shiraya, S.; Tanemoto, K.; Ogihara, T.; Kaneda, Y.; Morishita, R. Inhibitory effects of NFkB decoy oligodeoxynucleotides on neointimal hyperplasia in a rabbit vein graft model. J. Mol. Cell. Cardiol. 2006, 41, 431-440. [CrossRef]

76. Feeley, B.T.; Miniati, D.N.; Park, A.K.; Grant Hoyt, E.; Robbins, R.C. Nuclear factor-kB transcription factor decoy treatment inhibits graft coronary artery disease after cardiac transplantation in rodents. Transplantation 2000, 70, 1560-1568. [CrossRef]

77. Miyake, T.; Ihara, S.; Miyake, T.; Tsukada, Y.; Watanabe, H.; Matsuda, H.; Kiguchi, H.; Tsujimoto, H.; Nakagami, H.; Morishita, R. Prevention of neointimal formation after angioplasty using nuclear factor-KB Decoy oligodeoxynucleotide-coated balloon catheter in rabbit model. Circ. Cardiovasc. Interv. 2014, 7, 787-796. [CrossRef]

78. Tomita, N.; Morishita, R.; Tomita, S.; Yamamoto, K.; Aoki, M.; Matsushita, H.; Hayashi, S.I.; Higaki, J.; Ogihara, T. Transcription factor decoy for nuclear factor- $\mathrm{kB}$ inhibits tumor necrosis factor- $\alpha$-induced expression of interleukin- 6 and intracellular adhesion molecule-1 in endothelial cells. J. Hypertens. 1998, 16, 993-1000. [CrossRef]

79. Yoshimura, S.; Morishita, R.; Hayashi, K.; Yamamoto, K.; Nakagami, H.; Kaneda, Y.; Sakai, N.; Ogihara, T. Inhibition of intimal hyperplasia after balloon injury in rat carotid artery model using cis-element 'decoy'of nuclear factor-kB binding site as a novel molecular strategy. Gene Ther. 2001, 8, 1635. [CrossRef]

80. Yamasaki, K.; Asai, T.; Shimizu, M.; Aoki, M.; Hashiya, N.; Sakonjo, H.; Makino, H.; Kaneda, Y.; Ogihara, T.; Morishita, R. Inhibition of $\mathrm{NF}_{\kappa} \mathrm{B}$ activation using cis-element 'decoy' $\mathrm{N}$ NFKB binding site reduces neointimal formation in porcine ballooninjured coronary artery model. Gene Ther. 2003, 10, 356. [CrossRef]

81. Wang, Y.; He, L.; Du, Y.; Zhu, P.; Huang, G.; Luo, J.; Yan, X.; Ye, B.; Li, C.; Xia, P. The long noncoding RNA lncTCF7 promotes self-renewal of human liver cancer stem cells through activation of Wnt signaling. Cell Stem Cell 2015, 16, 413-425. [CrossRef]

82. Al-Azab, M.; Qaed, E.; Ouyang, X.; Elkhider, A.; Walana, W.; Li, H.; Li, W.; Tang, Y.; Adlat, S.; Wei, J. TL1A/TNFR2-mediated mitochondrial dysfunction of fibroblast-like synoviocytes increases inflammatory response in patients with rheumatoid arthritis via reactive oxygen species generation. FEBS J. 2020, 287, 3088-3104. [CrossRef] [PubMed]

83. Li, X.Y.; Hou, H.T.; Chen, H.X.; Wang, Z.Q.; He, G.W. Increased circulating levels of tumor necrosis factor-like cytokine 1A and decoy receptor 3 correlate with SYNTAX score in patients undergoing coronary surgery. J. Int. Med. Res. 2018, 46, 5167-5175. [CrossRef] [PubMed]

84. Chang, T.Y.; Hsu, C.Y.; Huang, P.H.; Chiang, C.H.; Leu, H.B.; Huang, C.C.; Chen, J.W.; Lin, S.J. Usefulness of Circulating Decoy Receptor 3 in Predicting Coronary Artery Disease Severity and Future Major Adverse Cardiovascular Events in Patients with Multivessel Coronary Artery Disease. Am. J. Cardiol. 2015, 116, 1028-1033. [CrossRef] [PubMed]

85. An, H.-J.; Kim, J.-Y.; Gwon, M.-G.; Gu, H.; Kim, H.-J.; Leem, J.; Youn, S.W.; Park, K.-K. Beneficial Effects of SREBP Decoy Oligodeoxynucleotide in an Animal Model of Hyperlipidemia. Int. J. Mol. Sci. 2020, 21, 552. [CrossRef]

86. Tomita, N.; Tomita, T.; Yuyama, K.; Tougan, T.; Tajima, T.; Ogihara, T.; Morishita, R. Development of novel decoy oligonucleotides: Advantages of circular dumb-bell decoy. Curr. Opin. Mol. Ther. 2003, 5, 107-112. [PubMed]

87. Crinelli, R.; Bianchi, M.; Gentilini, L.; Palma, L.; Sørensen, M.D.; Bryld, T.; Babu, R.B.; Arar, K.; Wengel, J.; Magnani, M. Transcription factor decoy oligonucleotides modified with locked nucleic acids: An in vitro study to reconcile biostability with binding affinity. Nucleic Acids Res. 2004, 32, 1874-1885. [CrossRef] 